\title{
A Place-BASED THEORY OF STANDING
}

\author{
Daniel A. Farber
}

Standing doctrine is well-knoum to be a quagmire, plagued by inconsistent results and judicial dissension. Worse, leading scholars have cast doubt on its historical pedigree and conceptual underpinnings. Yet, there seems to be little prospect for a radical change in direction. This Article proposes a more modest doctrinal shift. The proposed approach is much simpler than the current test, but preserves the core intuition that plaintiffs must have some special connection to the subject matter of the dispute, as opposed to a generalized interest in law enforcement or public policy. The proposal addresses standing in environmental cases, which form a major part of the U.S. Supreme Court's standing jurisprudence. The place-based standard is easily stated. Under this approach, a plaintiff has standing to contest environmental violations involving a specific geographic area, provided that the plaintiff has an appropriate personal connection to the area. The place-based approach would clarify and simplify existing doctrine, but without working a revolution. The Court's two most recent environmental standing decisions are not only consistent with this test, but quite readily resolved. People who live near and use a stream are obviously appropriate individuals to litigate issues relating to the pollution of the stream, as the Court correctly concluded in the Laidlaw case. And no one has a better claim than a state government to litigate harms to that state's environment—and even more so, potential erosion of that state's territory. Thus, Massachusetts v. EPA is also an easy case under the place-based approach.

INTRODUCTION

I. A BRIEF HISTORY OF STANDING …………………...................................1510

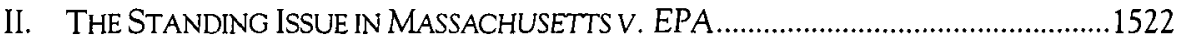

A. Massachusetts and General Issues in Standing Law .......................................1522

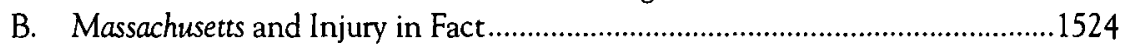

C. The Gospel According to Roberts ...............................................................1527

III. THE WEAKNESS OF CURRENT APPROACHES …………....................................1530

A. The Separation of Powers Argument.............................................................1530

B. Injury in Fact and Its Discontents...............................................................1538

1. Standing Doctrine as a Large Judicial Investment

With Haphazard Results.

* Sho Sato Professor of Law and Faculty Director of the California Center for Environmental Law and Policy, University of California, Berkeley. I would like to thank Eric Biber and Anne Joseph O'Connell for their helpful comments. 
2. A Dubious Constitutional Foundation ................................................1543

IV. THE PlaCE-BASED APPROACH TO ENVIRONMENTAL STANDING ...........................1547

A. The Argument for a Distinctive Definition

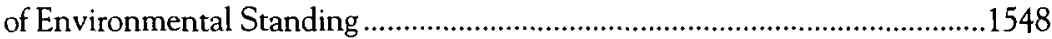

B. Reinterpreting Injury in Fact in Terms of Geographical Nexus ......................1550

C. Refining the Theory of Place-Based Standing................................................1552

D. Applying the Place-Based Approach .............................................................1554

CONCLUSION

\section{INTRODUCTION}

In his dissent from the U.S. Supreme Court's first environmental standing case, Justice Blackmun took the occasion to quote a famous passage from John Donne:

No man is an Iland, intire of itselfe; every man is a peece of the Continent, a part of the maine; if a Clod bee washed away by the Sea, Europe is the lesse, as well as if a Promontorie were, as well as if a Mannor of thy friends or of thine owne were; any man's death diminishes me, because I am involved in Mankinde; And therefore never send to know for whom the bell tolls; it tolls for thee. ${ }^{1}$

Climate change, the subject of the Court's most recent decision on the issue of environmental standing in Massachusetts v. EPA, exemplifies the inescapable interdependencies to which Donne (and later Blackmun) referred. The state of Massachusetts argued specifically that the Massachusetts coast would be "washed away by the Sea" due to rising sea levels and that the state would be "the lesse" as a result-this is indeed a bell that tolls for all of us. ${ }^{3}$

1. Sierra Club v. Morton, 405 U.S. 727, 760 n.2 (1972) (Blackmun, J., dissenting).

2. $127 \mathrm{~S}$. Ct. 1438 (2007). For discussion of the decision's implications for standing doctrine, see Access to Courts After Massachusetts v. EPA: Who Has Been Left Standing?, 37 ENVTL. L. REP. 10692 (2007).

3. The state's claim of injury was as follows:

According to petitioners' unchallenged affidavits, global sea levels rose somewhere between 10 and 20 centimeters over the 20th century as a result of global warming. These rising seas have already begun to swallow Massachusetts' coastal land. Because the Commonwealth "owns a substantial portion of the state's coastal property," it has alleged a particularized injury in its capacity as a landowner. The severity of that injury will only increase over the course of the next century: If sea levels continue to rise as predicted, one Massachusetts official believes that a significant fraction of coastal property will be "either permanently lost through inundation or temporarily lost through periodic storm surge and flooding events."

Massachusetts v. EPA, 127 S. Ct. at 1457 (internal citations and quotations omitted). 
In Massachusetts v. EPA, the Court took a generous view of the state's standing to challenge the federal government's failure to respond to global climate change. This ruling, which was accompanied by a dissent lamenting the Court's apostasy to existing standing dogma, ${ }^{4}$ provides an apt occasion to reconsider the Court's general approach. Few people maintain that the current situation is satisfactory. Even the Justices themselves seem unhappy. As we will see, every recent environmental standing decision has, like Massachusetts v. EPA, led to an acrimonious division on the Court about the application of the doctrine. This division has not been due to any fundamental disagreement among the Justices about the applicable rules, but rather apparently no one can agree on the purpose of the rules or their application.

The difficulties of standing law are belied by apparently simple and wellsettled doctrinal formulations. Even twenty years ago, a leading scholar on the subject (and now a federal judge) described the doctrine as "numbingly familiar." In any event, the simple three-part test to establish standing requirements under Article III of the U.S. Constitution can be easily stated: A plaintiff must demonstrate the existence of an "injury in fact" that is (1) "legally cognizable," (2) "fairly traceable" to the defendant, and (3) capable of being "redressed" by the court. "Each of the terms in quotation marks seems clear enough on the surface, yet, to the dismay of judges, litigants, and law students, each has proved remarkably tricky in practice. ${ }^{7}$ The case law in the area has long been renowned for its inconsistency, ${ }^{8}$ and cases have sometimes seemed oblivious to environmental concerns. ${ }^{9}$

The Court's inability to reach a consensus on the application of the test for standing in most of the cases it considers is a sign of trouble. A test that cannot be consistently applied fails in its primary function of guiding decisions. Given this, much could be said for simply abandoning

4. Id. at 1463 (Roberts, C.J., dissenting).

5. William A. Fletcher, The Structure of Standing, 98 YALE L.J. 221, 222 (1988).

6. See, e.g., Lujan v. Defenders of Wildlife, 504 U.S. 555, 560-61 (1992); Gene R. Nichol, Jr., Rethinking Standing, 72 CAL. L. REV. 68, 71-73 (1984).

7. Judge William Fletcher refers to "the apparent lawlessness of many standing cases when the wildly vacillating results in those cases are explained in the analytic terms made available by current doctrine." Fletcher, supra note 5, at 223.

8. See Nichol, supra note 6, at 71 (also remarking that the "law of standing is dominated by slogans and litanies").

9. See Richard J. Lazarus, Restoring What's Environmental About Environmental Law in the Supreme Court, 47 UCLA L. REV. 703, 749-52 (2000). 
the "injury in fact" concept that is so central to current standing doctrine." Whatever the appeal of that course, however, it seems quixotic to advocate such a radical departure, and doubtful that the Court will be prepared to jettison "injury in fact" any time in the near future. Nevertheless, the current situation is deeply unsatisfactory.

This Article attempts to make a start at draining this doctrinal swamp. It proposes a new approach to standing in environmental cases, similar to the current one but simpler to apply. The current approach requires a double geographic nexus: Plaintiffs must first show that they have a nexus to a particular geographic area, and then must show a nexus between that area and the defendant's conduct, resulting in harm to the plaintiffs. This Article advocates retaining the core concept of the double geographic nexus, but streamlining the nexus concept and thus simplifying the test. Identifying the relevant locale is central to this proposed approach; it is best denominated a "place-based" test.

The place-based test is easily stated: A plaintiff has standing to contest environmental violations involving a specific geographic area, provided that the plaintiff has an appropriate personal connection to the area. The place-based approach would clarify and simplify existing doctrine, but without working itself into a revolution. The cases in which standing is most doubtful under current law are still arguably close under the new test, though in many cases standing could be more readily established. Thus, the proposed standard retains the basic pattern of results, but with easier application and perhaps a moderate shift toward easier standing.

Parts I and II begin by surveying the history of standing and then taking a close look at the standing issue in the Massachusetts case. The story is one of pendulum shifts: first toward generous standing, then back toward more restrictive standing, then back again toward a more generous approach. The formalization of the test has remained the same, but its application has proved unstable. The main advocate for a more restricted approach has been Justice Scalia, while various other Justices have taken the other side. As the Court changes membership and attitudes toward the executive branch and judiciary shift, standing doctrine is variously applied more leniently or more strictly in lengthy opinions that conceal as much as they reveal.

10. This argument is cogently presented in Cass R. Sunstein, What's Standing After Lujan? Of Citizen Suits, "Injuries," and Article III, 91 MICH. L. REV. 163 (1992). For citations to a raft of eminent authorities on federal jurisdiction who reject the "injury in fact" test in favor of an alternative approach, see id. at $166 \mathrm{n} .15$. William Fletcher presents a particularly noteworthy argument for this alternative approach, under which the key question is not the plaintiff's injury but rather the existence of a cause of action. See Fletcher, supra note 5. 
Justice Scalia has been the Court's main advocate for restricting standing doctrine, and Part III takes a hard look at the separation of powers arguments he has used to justify his position. Part III also examines the weaknesses of the injury-in-fact test. Justice Scalia has attempted to raise the stakes in the standing debate by arguing that generous standing impairs presidential authority, but this argument proves to be ungrounded. His theory rests on a vision of presidential power that lacks textual or historical support, as well as ignoring direct evidence about the Framers' understanding of judicial power. Disposing of unwarranted originalist arguments for making standing as restrictive as possible opens the door to more straightforward approaches that ask simply whether the plaintiff has some personal tie with the litigated issue. Thus, when we dismiss the supposed constitutional imperatives underlying restrictive standing, we are in a position to craft improved standards.

Part IV then develops the alternative place-based approach to environmental standing. Recent cases illustrate the advantages of the place-based test. The Court's two most recent environmental standing decisions are not only consistent with this test, but quite readily resolved. People who live near and use a stream are obviously appropriate individuals to litigate issues relating to the pollution of the stream, as the Court correctly concluded in Friends of the Earth, Inc. v Laidlaw Environmental Services (TOC), Inc. ${ }^{11}$ And no one has a better claim to litigate widespread harms to Massachusetts's environment than the state of Massachusetts itself-especially given the potential erosion of that state's territory. ${ }^{12}$

This test is straightforward and easily applied-a great advance over current doctrine. It would deny standing in some cases, but without adopting the stance that restricting standing is a good in and of itself. Unlike more sweeping proposals to rethink standing, however, it retains the core intuition underlying current standing doctrine that a plaintiff should have some personal connection with the subject matter of the litigation, rather than having merely a general interest in public policy or in ensuring legal obedience for its own sake.

The Conclusion provides some final thoughts. The Court may ultimately decide that there is no constitutional basis for requiring a personal link between the plaintiff and the subject matter of litigation. Nonetheless, this idea has intuitive appeal and is strongly entrenched.

11. 528 U.S. 167 (2000).

12. Massachusetts v. EPA, 127 S. Ct. 1438 (2007). 
It behooves us to see whether it can be made operational in a more sensible way than current doctrine has managed.

\section{A BRIEF HISTORY OF STANDING}

The Supreme Court has struggled with standing doctrine for almost four decades, with much of that struggle taking place in environmental cases. The Supreme Court decided seven major environmental standing cases before Massachusetts v. EPA. None of those cases was unanimous, and many featured 5-4 divisions.

The foundational case was Sierra Club v. Morton. ${ }^{13}$ The Sierra Club challenged a plan by Walt Disney Enterprises to build a $\$ 35$ million resort in the Mineral King Valley, which the Court described as "an area of great natural beauty nestled in the Sierra Nevada Mountains." "The Sierra Club challenged the plan but did not claim that its members would be directly injured by the construction of the resort. Instead, it invoked its status as a public interest group with a long-standing focus on preservation of the environment. This novel claim provided the occasion for the Court's articulation of the key concepts of modern standing law.

In its brief, the Sierra Club argued that it should be heard as a representative of the public interest, and that it could represent that interest more effectively than any private individual..$^{15}$ According to the Sierra Club's brief, "[i]t would not be amiss to think of the nation's national park and national forest land as property which [the U.S.] Congress entrusted to the Secretary of the Interior and the Secretary of Agriculture for the benefit of all Americans, including generations yet unborn," Accordingly, "why should not the [C]ourt have power to appoint the Sierra Club guardian ad litem for the beneficiaries of that trust?"'17 The brief also stressed that the Sierra Club "is the only actual (or indeed likely) spokesman for the public interest in the preservation of Mineral King from the effects of illegal action." ${ }^{18}$

13. 405 U.S. 727 (1972).

14. Id. at 728. One shudders to imagine ski guides with Mickey Mouse costumes on the slopes of this pristine locale.

15. See Petition for Writ of Certiorari at 12-13, Sierra Club v. Morton, 405 U.S. 727 (1972) (No. 70-34).

16. Id. at 33. The desirability of appointing guardians to represent future generations is discussed in CHRISTOPHER D. STONE, SHOULD TREES HAVE STANDING?: AND OTHER ESSAYS ON LAW, MORALS, AND THE ENVIRONMENT 65-80 (1996).

17. Brief for Petitioner at 33, Sierra Club, 405 U.S. 727 (1972) (No. 70-34).

18. Id. at 34 . 
In response to the Sierra Club's arguments, the Solicitor General's argument raised some general concerns about the extension of standing. These concerns are worth noting; they did not figure heavily in the Court's opinion in Sierra Club or other cases in the following decade, but they would eventually receive strong support from Justice Scalia. The Solicitor General argued:

If there is standing in this case, I find it very difficult to think of any legal issue arising in government which will not have to await one or more decisions of the Court before the administrator, sworn to uphold the law, can take any action. I'm not sure that this is good for the government. I'm not sure that it's good for the courts. I do find myself more and more sure that it is not the kind of allocation of governmental power in our tripartite constiturional system that was contemplated by the Founders.

I do not suggest that the administrators can act at their whim and without any check at all. On the contrary, in this area they are subject to continuous check by the Congress. Congress can stop this development any time it wants to. ${ }^{19}$

Notice that the Solicitor General did not distinguish between administrators' failure to follow the law and simple policy disagreements that Congress might have with the agency-both would be subject primarily to political checks.

The Supreme Court held that the Sierra Club lacked standing, but it did not embrace the Solicitor General's theory that the political process was the only redress. According to the Court, a plaintiff seeking judicial review of agency action must show two things: (1) an "injury in fact"; and (2) an interest "arguably within the zone of interests to be protected or regulated" by the statute that the agency is claimed to have violated. The Sierra Club had failed to show the necessary injury in fact to it or its members. This might have been a major obstacle to environmental standing, had not the Court defined injury in broad terms.

According to the Court, the Sierra Club could have established injury in fact merely by showing that some of its members used the area in question for recreational purposes. The aesthetic injury suffered by these members, who would no longer be able to hike through an unspoiled wilderness if the project was built, would have been sufficient to constitute an injury in fact not only as to the individual members, but also the organization to which they belonged. As the Court said, "[a]esthetic and environmental well-being, like economic well-being, are important ingredients of the quality

19. Sierra Club, 405 U.S. at 753 (Douglas, J., dissenting) (quoting from the Solicitor General's oral argument). 
of life in our society, and the fact that particular environmental interests are shared by the many rather than the few does not make them less deserving of legal protection through the judicial process. ${ }^{20}$ However, the Sierra Club had not made the appropriate allegations concerning its members' recreational use of Mineral King Valley. The case was remanded to allow the complaint to be amended.

The dissenters would have extended standing more broadly. Justice Douglas argued that cases should be brought in name of the river or woodland creature directly harmed by the defendant's actions. In practical terms, however, the results under the approach he advocated would have been similar to the Court's approach, with the ability to bring suit being based on a personal connection with the resource: "Those who hike [Mineral King Valley], fish it, hunt it, camp in it, frequent it, or visit it merely to sit in solitude and wonderment are legitimate spokesmen for it, whether they may be few or many." Justice Douglas's insight is central to the place-based approach to standing, and we will return to it in more detail later. For present purposes, it suffices to note that Douglas's proposal was much less radical than it might seem from his rhetoric about giving standing to trees and birds.

Justice Blackmun, in the same dissent in which he invoked John Donne, took an even broader view than Justice Douglas. He was apparently willing to dispense entirely with the requirement of a personal connection with the affected locality. Instead, he argued for "an imaginative expansion of our traditional concepts of standing in order to enable an organization such as the Sierra Club, possessed, as it is, of pertinent, bona fide, and well-recognized attributes and purposes in the area of the environment, to litigate environmental issues." 22 In a statement that he read aloud from the bench when the decision in the case was announced, he observed that "our emerging problems of the environment and ecological unbalance are worrisome problems indeed, and I am distressed that our law is so inflexible that we find ourselves helpless procedurally to meet these new problems."23 His proposal was in some ways more radical than that of Justice Douglas, since it would not require an environmental group to show any connection

20. Id. at 734 (majority opinion). For an incisive contemporaneous critique of the Sierra Club Court's insistence on a showing of interference with the interests of users of the resource, see Joseph L. Sax, Standing to Sue: A Critical Review of the Mineral King Decision, 13 NAT. RESOURCES J. 76 (1973).

21. Sierra Club, 405 U.S. at 744-45 (Douglas, J., dissenting).

22. Id. at 757 (Blackmun, J., dissenting).

23. Robert V. Percival, Environmental Law in the Supreme Court: Highlights From the Blackmun Papers, 35 ENVTL. L. REP. 10637, 10657 (2005). 
with the particular environmental resource involved in the litigation. Rather, some environmental groups would be authorized to act as roving guardians of Nature and Public Health.

Despite Justice Blackmun's practical concerns, the next Supreme Court case concerning environmental standing proved the Sierra Club test would not be difficult for environmental advocates to satisfy. United States $v$. Students Challenging Regulatory Agency Procedures ${ }^{24}$ (SCRAP) involved a challenge to an Interstate Commerce Commission (ICC) decision in a railroad rate case. The railroads had sought permission for a general rate increase to expand their revenues and to cover expenses. The ICC allowed the rate increase to go into effect temporarily pending investigation. The plaintiffs, a group of law students who had formed an association in order to bring the case, alleged that the existing rate schedule unfairly discriminated against recycled goods, and that this discrimination would be amplified by the proportional rate increase. The premise of the students' standing argument was that the ICC's approval of the rate increase would indirectly make their visits to local parks less pleasant because of an increase in litter from nonrecycled items. They also alleged that the decrease in recycling would increase mining and logging in the region where they lived, with detrimental environmental effects. ${ }^{25}$

Despite the attenuated chain of causation alleged by the plaintiffs, and the fairly minimal injury that they claimed as a result of this chain of causation, the Supreme Court held that they did have standing to challenge the ICC's action. As Professor Richard Pierce has observed, SCRAP set "an extremely low threshold for the nature and magnitude of the injury sufficient to obtain standing." Indeed, he noted that if the "Court had retained the approach it took in SCRAP, almost anyone would have standing to obtain review of almost any action that has an adverse effect on the environment." ${ }^{26}$

SCRAP clarified two elements of standing law. First, the Court made it clear that standing "is not to be denied simply because many people suffer the same injury."27 As the Court pointed out, to deny standing to individuals who are injured simply because many others are also injured would mean that the "most injurious and widespread Government actions could be questioned by nobody." 28 The contention that widespread injuries are

24. 412 U.S. 669 (1973).

25. Id. at 676 .

26. Richard J. Pierce, JR., Sidney A. Shapiro \& Paul R. Verkuil, Administrative LAW AND PROCESS 148 (4th ed. 2004).

27. SCRAP, 412 U.S. at 687.

28. Id. at 688 . 
disqualified from serving as a basis for standing has been forcefully advocated by Justice Scalia. ${ }^{29}$ Nevertheless, the Court has maintained SCRAP's vitality on the issue of standing-the Massachusetts Court specifically endorsed SCRAP in this respect. ${ }^{30}$

Second, the SCRAP Court held that the test for standing was qualitative, not quantitative. That is, the magnitude of the injury in fact makes no difference so long as some injury exists. As the Court said, quoting a noted administrative law scholar of the time, "[t]he basic idea that comes out in numerous cases is that an identifiable trifle is enough" to establish standing. ${ }^{31}$ What was required, in short, was that the plaintiffs allege "a specific and perceptible harm that distinguished them from other citizens who had not used the natural resources that were claimed to be affected." ${ }^{32}$

Like Sierra Club and SCRAP, the Supreme Court's next decision in Duke Power Co. v. Carolina Environmental Study Group, Inc. ${ }^{33}$ also took a generous approach to standing. The case involved a chain of causation almost as tenuous as that in the SCRAP case, though for some reason it has not come under as much fire from conservative justices on the Court. The plaintiffs in Duke Power challenged the constitutionality of a statute that limited the liability of the nuclear industry for damages resulting from a single nuclear accident. The plaintiffs claimed that if the industry were exposed to full liability, reactors would not be built, and that this in turn would spare the plaintiffs immediate environmental injuries. ${ }^{34}$ Thus, their standing claim was that, as a result of a statute which might be unconstitutional if it were ever actually applied to them in the future, they were suffering immediate environmental injury today. The lower court had ruled in their favor on the merits, so that if the case were dismissed for lack of standing a cloud would nevertheless lie on the nuclear industry. ${ }^{35}$ On appeal, the Supreme Court found standing and reversed on the merits.

Despite the tenuous chain of causation, the Court held that there was a substantial likelihood that the nuclear plants near the plaintiffs' homes would not be completed or operated without the statute. This likelihood was held to be a sufficient basis for standing, despite the lack of any logical

29. See infra Part III.A.

30. Massachusetts v. EPA, 127 S. Ct. at 1458 n.24.

31. SCRAP, 412 U.S. at 689 n.14 (quoting K. Davis, Standing: Taxpayers and Others, 35 U. CHI. L. REV. 601,613 (1968)).

32. Id. at 689 .

33. 438 U.S. 59 (1978).

34. Id. at 102 (Stevens, J., concurring).

35. See id. at 103 (Stevens, J., concurring) (arguing that the Court's decision serves the national interest in removing doubts about the statute's constitutionality). 
connection between this injury and their constitutional challenge to the liability limitation. ${ }^{36}$ The justices who endorsed standing in Duke Power were otherwise known for their generally restrictive attitudes toward standing, leaving a distinct impression that the outcome may have been driven by the desire to reverse the lower court ruling on the merits so as to support the viability of the nuclear industry.

Whatever the reason, the Duke Power Court followed the generous SCRAP approach to standing in environmental cases. In 1990, however, a greatly "reinvigorated and more restrictive" standing doctrine began to emerge. ${ }^{37}$ The first indication of a changed attitude toward environmental standing was a reference, in a nonenvironmental opinion, to SCRAP as involving "[p]robably the most attenuated injury" ever to confer standing, with the additional comment that SCRAP "surely went to the very outer limit of the law." ${ }^{38}$ (Why SCRAP was considered more dubious than the equally bold holding in Duke Power is unclear.)

A second, more serious signal followed later the same year, in Lujan v. National Wildlife Federation, ${ }^{39}$ in which the Court held that the plaintiff lacked standing to challenge a government program to open government lands to development interests through the Bureau of Land Management (BLM). What was striking about this case was not so much the holding itself but the Court's rhetoric. Justice Scalia's opinion for the Court held that the plaintiff's standing claims were invalid in two respects. First, the plaintiff had attempted to comply with Sierra Club by filing affidavits attesting to use of the affected lands by some of its members. The affidavits were defective, the Court held, because they only alleged that these members used federal lands "in the vicinity" of those affected by the government program. Justice Scalia concluded that actual presence, not merely vague proximity, was

36. See id. at 77-78 (majority opinion).

37. William W. Buzbee, The Story of Laidlaw: Standing and Citizen Enforcement, in ENVIRONMENTAL LAW STORIES 201, 215 (Richard J. Lazarus \& Oliver A. Houck eds., 2005).

38. Whitmore v. Arkansas, 495 U.S. 149, 158, 159 (1990).

39. 497 U.S. 871 (1990). National Wildlife Federation involved a Bureau of Land Management (BLM) review of past executive orders protecting many public lands from resource development. Id. In 1976, the U.S. Congress directed the BLM to review existing withdrawals in eleven western states and to decide whether the lands should be reopened for development. Id. at 879 . The plaintiff alleged that the BLM had violated the required statutory procedures in numerous respects, and that the BLM's action would open the lands to mining. Id. Between SCRAP and National Wildlife Federation, the Court did not decide any major environmental standing case, but rather it did offhandedly uphold the standing of an environmental group to challenge whaling rules in Japan Whaling Ass'n v. American Cetacean Society, 478 U.S. 221 (1986). The standing discussion occupied one sentence in a long footnote about whether the plaintiffs had a cause of action. Id. at $230 \mathrm{n} .4$. 
required. $^{40}$ Second, even if those affidavits had been adequate, they would have established the plaintiffs right to litigate only about the specific lands used by those individuals, not to challenge the entire BLM program. ${ }^{41}$ This case clearly signaled a more restrictive attitude toward standing, but did not represent so much a shift in doctrine as a demand for more careful drafting of affidavits. The tone of the opinion, however, indicated a heightened skepticism toward claims of environmental injury and a hostility to environmental plaintiffs.

The high point of Justice Scalia's campaign to restrict standing came in Lujan v. Defenders of Wildlife," which "directly raised the stringent litigation hurdle posed by standing doctrine." ${ }^{n 3}$ The ultimate issue in Defenders of Wildlife, which the Court never reached, was whether the Endangered Species Act (ESA) applies only to actions within the United States. The plaintiffs alleged that they would be harmed in various ways by federally supported actions taking place in Egypt and Sri Lanka, actions that would allegedly imperil certain endangered species. ${ }^{44}$ The Court held that they lacked standing, in the process holding the ESA's citizen-suit provision unconstitutional as applied to the case. Without any injury in fact, the plaintiffs could only be suing to vindicate an abstract interest in administrative compliance with the law. That interest, the Court said, is properly the concern not of the courts but of the president, who is constitutionally obligated to "take care that the Laws be faithfully executed." At least one prominent commentator found it "impossible to reconcile the reasoning and holding in Defenders of Wildlife with many of the Court's prior standing opinions. ${ }^{, 46}$

The plaintiffs in Defenders of Wildlife had unsuccessfully alleged several forms of injury. Two members alleged that they had visited the relevant areas of Egypt and Sri Lanka in the past and hoped to do so again in the future. "Such 'some day' intentions-without any description of concrete plans, or

40. Nat'l Wildlife Fed'n, 497 U.S. at 888-89.

41. Id. at 890-91. According to the Court, unless a statute specifically permits broad regulations to be directly reviewed, a plaintiff can only challenge some "concrete action applying the regulation to the claimant's situation in a fashion that harms or threatens to harm him." Id. at 891 . The opinion then points out that exceptions exist when provided by statutes such as the Clean Air Act or when a rule "as a practical matter requires the plaintiff to adjust his conduct immediately." Id. Thus, this requirement seems not to be constitutionally based, since it can be modified by Congress.

42. 504 U.S. 555 (1992).

43. Buzbee, supra note 37, at 216.

44. Defenders of Wildlife, 504 U.S. at 562-64.

45. Id. at 577 .

46. PIERCE, SHAPIRO \& VERKUIL, supra note 26, at 151. For another extensive critique of the opinion, see Sunstein, supra note 10, at 202-22. 
indeed even any specification of when the some day will be," were not enough to support standing. ${ }^{47}$ Justice Scalia was no more impressed with the plaintiffs' other standing theories. ${ }^{48}$ The first of these theories was labeled as the ecosystem nexus, under which (at least according to Justice Scalia) "any person who uses any part of a 'contiguous ecosystem' adversely affected by a funding activity has standing even if the activity is located a great distance away. ${ }^{, 99}$ Although the ESA is aimed in part at the protection of ecosystems, Justice Scalia found no basis for concluding that it created a cause of action on behalf of people who use parts of the ecosystem "not perceptibly affected" by the government's action. ${ }^{50}$

Justice Scalia was equally unimpressed by the plaintiffs' other two theories. One, which they called the animal nexus, would have conveyed standing on anyone who studies or observes an endangered species. The other theory, the vocational nexus, would grant standing to anyone with a professional interest in the animal. Although it does not seem particularly strange to suggest that someone whose career is devoted to studying or to preserving members of the species has a legitimate interest in protecting the viability of the species, Justice Scalia apparently found it bizarre that anyone would argue for standing under this theory. He could scarcely believe what he paraphrased as a claim that "anyone who goes to see Asian elephants in the Bronx Zoo... has standing to sue because the Director of the Agency for International Development (AID) did not consult with the Secretary [of Interior] regarding the AID-funded project in Sri Lanka." "51 "It goes beyond the limit," he said, "and into pure speculation and fantasy, to say that anyone who observes or works with an endangered species, anywhere in the world, is appreciably harmed by a single project affecting some portion of that species with which he has no more specific connection." ${ }^{52}$ The rhetorical tone of the opinion, even more than its content, heralded a more skeptical attitude toward environmental standing. Clearly, Justice Scalia viewed environmental groups not as well-motivated advocates for important public interests, but rather as special interests willing to distort common sense in pursuit of their goals.

47. Defenders of Wildlife, 504 U.S. at 564 .

48. The adjectives novel and creative are seldom compliments when judges use them to refer to legal theories.

49. 504 U.S. at 565.

50. Id. at 566 .

51. Id.

52. Id. at 567. 
A concurrence by Justice Kennedy, joined by Justice Souter, attempted to stake out a middle ground. It received less attention, probably because its rhetoric was so much more subdued and less arresting. The Kennedy concurrence deserves careful attention, however, for two reasons. First, Justice Kennedy and Justice Souter were the swing voters in Defenders of Wildlife, and although the concurrence was not widely noted at the time, it added significant caveats to the holding in the case. In light of some of the qualifications presented by this concurrence, Justice Scalia's opinion may never actually have represented a majority of the Court, even in those sections not formally designated as merely joined by a plurality. Second, the Kennedy concurrence turned out to be highly influential in Massachusetts v. EPA. ${ }^{53}$ In contrast, Justice Scalia's majority opinion now seems like an outlier.

Justice Kennedy entered significant qualifications to the central arguments in Justice Scalia's opinion, to the point where he might almost as well have written a dissent. He agreed that the record in was inadequate to support the plaintiff's nexus theories, but was not willing to foreclose them in some future case as a matter of law. He also saw a greater role for Congress in defining the perimeter of injury in fact:

As Government programs and policies become more complex and farreaching [sic], we must be sensitive to the articulation of new rights of action that do not have clear analogs in our common-law tradition.... In my view, Congress has the power to define injuries and articulate chains of causation that will give rise to a case or controversy where none existed before .... In exercising this power, however, Congress must at the very least identify the injury it seeks to vindicare and relate the injury to the class of persons entitled to bring suit. The citizen-suit provision of the Endangered Species Act does not meet these minimal requirements. . . . ${ }^{54}$

In contrast, Justice Scalia's opinion seemed to give Congress no power to modify the application of the injury-in-fact test.

Despite Justice Kennedy's quiet demurrer, Defenders of Wildlife and National Wildlife Foundation seemed to signal a sharply restrictive attitude toward standing. This trend was ostensibly confirmed by Steel Co. v. Citizens for a Better Environment, ${ }^{55}$ which concerned the ability of the plaintiff to bring a citizen suit against a company for past violations of a reporting statute. The Court held that the third prong of standing, redressability, was absent; the

53. See infra text accompanying notes 80-82.

54. 504 U.S. at 580 (Kennedy, J., dissenting) (citations omitted).

55. 523 U.S. 83 (1998). 
plaintiffs had no right to damages and any other judicial remedy would fail to address their injury from past violations. Justice Scalia, the author of the opinion, had seemingly won another battle in his campaign to restrict standing. Several subsequent court of appeals decisions in water pollution cases expanded on this holding. ${ }^{56}$

The tide turned, however, in the Court's next standing decision, Friends of the Earth Inc. v. Laidlaw Environmental Services (TOC), Inc. ${ }^{57}$ Laidlaw involved a citizen suit under the Clean Water Act, in which the plaintiffs attempted to obtain payment of civil penalties for pollution that had ceased before the district court's judgment. ${ }^{58}$ The defendant had purchased a hazardous waste incinerator that discharged into a South Carolina river. ${ }^{59}$ The act imposed stringent limits on mercury discharges, which the company failed to meet on numerous occasions. ${ }^{60}$ The district court later found, perhaps erroneously, that the discharges did not cause measurable harm to the river's ecology or pose a health threat. ${ }^{61}$

Court watchers had expected the decision to focus on whether later events would render the suit moot and were surprised that the Court's opinion gave equal attention to standing. ${ }^{62}$ Standing had not been a focal point at the oral argument. ${ }^{63}$ There was, however, one notable interchange relating to standing. At oral argument, Justice Scalia had made a "largely impenetrable" comment equating citizen suits with "[q]ui tam squared." that, although I'm not sure I understand it." ${ }^{.65}$ He later explained his thoughts: "Anything this guy says, I'm agreeing with him." Events would confirm the lawyer's perception: Justice Scalia did strongly support his

56. See Buzbee, supra note 37 , at 222-24.

57. 528 U.S. 167 (2000). For an explanation of how Laidlaw fits into the prior line of standing cases, see Michael P. Healy, Standing in Environmental Citizen Suits: Laidlaw's Clarification of the Injury in Fact and Redressability Requirements, 30 ENVTL. L. REP. 10455 (2000).

58. See Laidlaw, 528 U.S. at 167.

59. See id. at 176-79.

60. See id. at 176 .

61. See id. at 181 .

62. Buzbee, supra note 37, at 227.

63. Id. at 227. After Friends of the Earth gave notice of its intent to file a citizen suit, the company contacted the state environmental agency and arranged a sweetheart deal under which it agreed to make every effort to comply with the permit and paid a modest fine. Friends of the Earth nevertheless filed a citizen suit, and the violations continued long afterwards, though they ceased before judgment was entered. While the case was on appeal, the plant was allegedly closed permanently and the site put up for sale. Laidlaw, 528 U.S. at 189.

64. Buzbee, supra note 37 , at 227.

65. Id.

66. Id. 
position on the absence of standing. Unfortunately for the lawyer and his client, Scalia's was not the majority view.

Instead, the Court gave the plaintiff standing with little hesitation. The district court's finding of "no demonstrated... harm to the environment" clearly supported an argument that the plaintiffs lacked the requisite injury in fact. In reaching the contrary conclusion, the Court relied on affidavits filed by members of the plaintiff organization. For instance, one member said he lived a half mile from the river and would like to use it (and its surroundings) for recreational purposes, as he had when he was younger. ${ }^{68}$ But when he occasionally drove across a bridge over the river, it looked and smelled polluted, and as a result he did not make use of the river "because of his concerns about Laidlaw's discharges." sufficient basis for standing.

In a sharp dissent, joined only by Justice Thomas, Justice Scalia was incredulous that these allegations would suffice as a basis for standing, particularly given the absence of the lower courts' careful consideration of the issue:

By accepting plaintiffs' vague, contradictory, and unsubstantiated allegations of "concern" about the environment as adequate to prove injury in fact, and accepting them even in the face of a finding that the environment was not demonstrably harmed, the Court makes the injury-in-fact requirement a sham. If there are permit violations, and a member of a plaintiff environmental organization lives near the offending plant, it would be difficult not to satisfy today's lenient standard. ${ }^{70}$

The Court's response was two-fold. First, the Court carefully distinguished prior cases on their facts. "This reflects a noteworthy change in emphasis, from a rule-based approach to a more common law, case-by-case approach. Justice Scalia's opinions, in particular, had often featured sweeping language rather than detailed factual inquiries.

Second, the Court refashioned the notion of injury. The phrase injury in fact suggests that we should look at the tangibility of the impairment suffered by the plaintiff, so that some types of harms (like financial losses) qualify as injury in fact, while others (such as mere psychological

67. Laidlaw, 528 U.S. at 181.

68. Id. at $181-82$.

69. Id. at 182. Other affidavits were similar. See id. at 182-83.

70. Id. at 201 (Scalia, J., dissenting) (citation omitted).

71. See id. at 183-86 (majority opinion). 
apprehensions) do not. Justice Scalia relied upon this approach in his dissent. ${ }^{72}$ In the Court's view, however,

the only "subjective" issue here is "[t]he reasonableness of [the] fear" that led the affiants to respond to that concededly ongoing conduct by refraining from use of the North Tyger River and surrounding areas.... [W] company's continuous and pervasive illegal discharges of pollutants into a river would cause nearby residents to curtail their recreational use of that waterway and would subject them to other economic and aesthetic harms. The proposition is entirely reasonable, the District Court found it was true in this case, and that is enough for injury in fact. ${ }^{73}$

The Court's analysis shifts the focus from the impact on the plaintiff alone, to the disruption of the plaintiff's relationship with the river. In this respect, it is reminiscent of Justice Douglas's view in Sierra Club that those who have an "intimate relation with the inanimate object about to be injured, polluted, or otherwise despoiled are its legitimate spokesmen." ${ }^{74}$ In this respect, Laidlaw presages the place-based approach to standing.

Laidlaw was immediately interpreted by the lower courts as an expansion of standing. For example, in Friends of the Earth, Inc. v. Gaston Copper Recycling Corp.,${ }^{75}$ the Fourth Circuit in finding standing relied upon a plaintiff's testimony that he would fish and swim in a lake more often if pollution were abated. The averred inhibition to the plaintiffs activities was found sufficient to demonstrate injury in fact, despite the lack of evidence regarding chemical content, an increase in salinity, or any other negative change in the ecosystem of the waterway. ${ }^{76}$ Similarly, in Ecological Rights Foundation v. Pacific Lumber Co., ${ }^{7}$ the Ninth Circuit explained that the necessary connection between an individual and the "area of concern" need only be sufficient to "make credible the contention that the person's

72. See id. at 199 (Scalia, J., dissenting) (citing Los Angeles v. Lyons, 461 U.S. 95, 107 n.8 (1983)).

73. Id. at 184-85 (majority opinion); see also Duke Power Co. v. Carolina Envtl. Study Group, Inc., 438 U.S. 59, 74 (1978) ('[E]mission of non-natural radiation into appellees' environment [without any proof of health risk] would also seem a direct and present injury, given our generalized concern about exposure to radiation and the apprehension flowing from the uncertainty about the health and genetic consequences of even small emissions like those concededly emitted by nuclear power plants.").

74. Sierra Club v. Morton, 405 U.S. 727, 745 (1972) (Douglas, J., dissenting). Douglas's dissent is better known for his advocacy of granting standing to the inanimate objects themselves.

75. 204 F.3d 149 (4th Cir. 2000).

76. Id. at 155 .

77. 230 F.3d 1141 (9th Cir. 2000). 
future life will be less enjoyable-that he or she really has or will suffer in his or her degree of aesthetic or recreational satisfaction-if the area in question remains or becomes environmentally degraded." ${ }^{18}$

Although Laidlaw was a setback for Justice Scalia's restrictive view of standing, worse was yet to come. The problem of global climate change would soon reach the Supreme Court, and the issue of standing featured prominently. ${ }^{79}$ The Court would use the case to further weaken restrictions on standing.

\section{THE STANDING ISSUE IN MASSACHUSETTS V. EPA}

In Massachusetts v. EPA, states, local governments, and environmental organizations sought judicial review of the EPA's denial of their petition, which had asked the EPA to initiate a rulemaking process regarding greenhouse gas emissions from motor vehicles under $\S 202$ of the Clean Air Act. ${ }^{80}$ A divided panel of the D.C. Circuit ruled in favor of the EPA, partly based on questions about the petitioners' standing. ${ }^{81}$ On certiorari, Justice Stevens, writing for the Court, held that the plaintiff did have standing.

\section{A. Massachusetts and General Issues in Standing Law}

Before turning to the conventional tripartite test for standing, the Court made four preliminary points. The first was that the Court was following congressional instructions to determine the legality of agency conduct, noting that "[t]he parties' dispute turns on the proper construction of a congressional

78. Id. at 1149. More recently, the D.C. Circuit applied Laidlaw to uphold an environmental organization's standing to challenge rules exempting certain sources from rules governing hazardous air pollutants (HAPs):

Two members of the petition organizations live near PCWP [plywood and composite wood products] facilities that are exempt as low-risk facilities from all HAP controls. Holly Clark, a member of NRDC, states that she lives near the exempt facility in Rocklin, California. She monitors the air quality reports and on particularly polluted days she cuts back on her ourdoor activities, including her gardening, and she does not drive her car. In the past 17 years she has seen the horizon become visibly smoggier; although she was once able to see the Sacramento skyline, she no longer can.... These are the kinds of harms that the Supreme Court in Laidlaw determined were sufficient to show injury-in-fact . . . .

Natural Res. Def. Council v. EPA, 489 F.3d 1364, 1370-71 (D.C. Cir. 2007).

For more on the implications of Laidlaw, see Daniel A. Farber, Environmental Litigation After Laidlaw, 30 ENVTL. L. REP. 10516 (2000).

79. More than half of the oral argument in Massachusetts v. EPA, 127 S. Ct. 1438 (2007), focused on the standing issue. See Oliver A. Houck, Standing on the Wrong Foot: A Case for Equal Protection, 58 SYRACUSE L. REV. 1, 1 n.2 (2007).

80. 127 S. Ct. 1438, 1449-51 (2007) (referencing 42 U.S.C. $\$ 7521(2000)$ ).

81. Massachusetts v. EPA, 415 F.3d 50 (D.C. Cir. 2005). 
statute, a question eminently suitable to resolution in federal court. ${ }^{, 82}$ The Court also stressed that Congress had authorized such challenges to EPA actions, a fact of critical importance to the standing inquiry:

"Congress has the power to define injuries and articulate chains of causation that will give rise to a case or controversy where none existed before." "In exercising this power, however, Congress must at the very least identify the injury it seeks to vindicate and relate the injury to the class of persons entitled to bring suit." We will not, therefore, "entertain citizen suits to vindicate the public's nonconcrete interest in the proper administration of the laws." ${ }^{83}$

Note that the internal quotations in this passage are from the Kennedy concurrence in Defenders of Wildlife. The Massachusetts Court's approving recitation thereby transformed a concurring judge's troubled caveats to square judicial holdings. Justice Kennedy's quiet voice thus triumphed over Justice Scalia's oratorical thetoric. Also note that the statutory provision in question was fairly general; Congress had not, for example, created a special standing rule for climate change victims. ${ }^{84}$

Second, the Court rejected the assertion that injuries are disqualified from serving as a basis for standing merely because they are widespread. Again, the Court relied on Justice Kennedy's Defenders of Wildlife concurrence for this proposition, quoting a key passage from that opinion. ${ }^{85}$ As we will see, this amounted to a rejection of a key element of Justice Scalia's theory of standing. ${ }^{86}$ This aspect of SCRAP remained firm.

Third, the Court stressed that the test for standing is easier to meet when a procedural right is involved:

[A] litigant to whom Congress has "accorded a procedural right to protect his concrete interests,"-here, the right to challenge agency action unlawfully withheld-" can assert that right without meeting all the normal standards for redressability and immediacy." When a litigant is vested with a procedural right, that litigant has standing if there is some possibility that the requested relief will prompt the injury-causing party to reconsider the decision that allegedly harmed the litigant. ${ }^{87}$

82. \127 S. Ct. at 1453.

83. Id. (quoting Lujan v. Defenders of Wildlife, 504 U.S. 555, 580 (1992) (Kennedy, J., concurring)).

84. Id. at 1454 .

85. Id. at 1453 (quoting Defenders of Wildlife, 504 U.S. at 580 (Kennedy, J., concurring)).

86. See infra text accompanying notes 120-151.

87. $127 \mathrm{~S}$. Ct. at 1453 (citations omitted). 
The idea that procedural injuries have a lower threshold for standing was not new, ${ }^{88}$ but the Court had not previously indicated that judicial review of an agency action might itself be a component of such a "procedural" right. When it grants plaintiffs a cause of action, Congress apparently does not eliminate the need to show some form of injury in fact, but it creates a procedural right that in turn calls for a lower threshold of injury than might otherwise be required.

Fourth, because some of the plaintiffs were state governments, the Court suggested that their standing claim should be treated with particular generosity. Having surrendered some of their sovereign abilities to protect their environments when they entered the union-for example, the ability to negotiate for greenhouse gas reductions with foreign powers-states were now reliant on Congress to help protect their "quasi-sovereign interests."

Of the Court's four general assertions about standing law, the first three were either familiar from earlier opinions or supported by Justice Kennedy's Defenders of Wildlife concurrence. The final point about the standing of state governments was the most novel. ${ }^{90}$ But the Court's view seems plausible enough. Massachusetts would surely have standing to litigate a claim by a neighboring state that the state line should be moved inwards a foot; it should similarly have a cognizable harm when it is the sea rather than a neighbor attacking its territorial integrity.

\section{B. Massachusetts and Injury in Fact}

With these preliminaries in mind, the Court turned to the tripartite standing test. Addressing the first element, injury in fact, the Court said:

The harms associated with climate change are serious and well recognized. Indeed, the NRC Report itself-which [the] EPA regards as an "objective and independent assessment of the relevant

88. For instance, see Earth Island Inst. ข. Ruthenbeck, 490 F.3d 687 (9th Cir. 2007) (finding that organizations had standing to challenge regulations that precluded administrative appeals of certain Forest Service decisions).

89. $127 \mathrm{~S}$. Ct. at $1454-55$. This portion of the discussion has some significant implications for federalism issues in climate change regulation. See Daniel A. Farber, Climate Change, Federalism, and the Constitution, 50 ARIZ. L. REV. (forthcoming 2008), available at http://papers.ssrn.com/ sol3/papers.cfm?abstract_id $=1081664$.

90. It should be noted that some lower courts have recognized distinctive types of injuries relating to state governments in environmental cases. See, e.g., Nat'l Ass'n of Clean Air Agencies v. EPA, 489 F.3d 1221, 1227-28 (D.C. Cir. 2007) (finding that state agencies have standing when a new EPA rule would allow increased pollution from some sources and thereby make it more difficult for them to establish state implementation plans; citing Massachusetts v. EPA as well as earlier circuit authority). 
science"-identifies a number of environmental changes that have already inflicted significant harms, including "the global retreat of mountain glaciers, reduction in snow-cover extent, the earlier spring melting of rivers and lakes, [and] the accelerated rate of rise of sea levels during the 20th century relative to the past few thousand years . . .."91

The Court noted that these effects posed a particular threat to the state's interests: "If sea levels continue to rise as predicted, one Massachusetts official believes that a significant fraction of coastal property will be 'either permanently lost through inundation or temporarily lost through periodic storm surge and flooding events."'92 "Remediation costs alone, petitioners allege, could run well into the hundreds of millions of dollars." ${ }^{193}$

As to causation, the second element, the EPA did "not dispute the existence of a causal connection between man-made greenhouse gas emissions and global warming." ${ }^{14}$ The EPA did contend, however, that the particular government action that the plaintiffs sought would not have a significant impact in abating the effects of climate change, because automobiles are only one source of greenhouse gases and because the United States as a whole accounts for only a portion of these gases. The Court rejected this "erroneous assumption that a small incremental step, because it is incremental, can never be attacked in a federal judicial forum. ${ }^{195}$ Instead, the Court stressed that "[a]gencies, like legislatures, do not generally resolve massive problems in one fell regulatory swoop" but "whittle away at them over time, refining their preferred approach as circumstances change and as they develop a more nuanced understanding of how best to proceed." Moreover, this particular first step would be far from insignificant: "Considering just emissions from the transportation sector, which represent less than one-third of this country's total carbon dioxide emissions, the United States would still rank as the

91. 127 S. Ct. at 1455 (citations omitted).

92. Id. at 1456 .

93. Id.

94. Id. at 1457. This element of standing had loomed increasingly large after Defenders of Wildlife. Causation had posed a fatal stumbling block to standing for environmental plaintiffs in various contexts. For example, in Friends of the Earth, Inc. v. Croum Central Petroleum Corp., 95 F.3d 358 (5th Cir. 1996), the court denied standing to plaintiffs who birdwatched and fished at a lake eighteen miles (and three tributaries) away from the pollution source. The plaintiffs had offered no evidence that the pollution actually affected the lake. See also Texas Indep. Producers \& Royalty Owners Ass'n v. EPA, 410 F.3d 964, 974 (7th Cir. 2005) (noting that the National Resources Defense Council (NRDC) failed to show causation in a challenge to a permit allowing storm water discharges by construction sites into numerous water bodies, where it failed to name any specific construction sites); Fa. Audubon Soc'y v. Bentsen, 94 F.3d 658 (D.C. Cir. 1996) (en banc) (finding as too speculative the claim that a tax credit for a fuel additive would increase com and sugar production, resulting in environmental harms).

95. $127 \mathrm{~S}$. Ct. at 1457. 
third-largest emitter of carbon dioxide in the world, outpaced only by the European Union and China. ${ }^{, 96}$

Finally, the Court was untroubled by the remedial issues of the third element. "While it may be true that regulating motor-vehicle emissions will not by itself reverse global warming, it by no means follows that we lack jurisdiction to decide whether [the] EPA has a duty to take steps to slow or reduce it. ${ }^{, 97}$ As the Court noted, the government had strongly supported voluntary efforts to reduce greenhouse gases, and it would "presumably not bother with such efforts if it thought emissions reductions would have no discernable impact on future global warming."

Summarizing the Court's holding on standing, Justice Stevens said:

In sum-at least according to petitioners' uncontested affidavits-the rise in sea levels associated with global warming has already harmed and will continue to harm Massachuserts. The risk of catastrophic harm, though remote, is nevertheless real. That risk would be reduced to some extent if petitioners received the relief they seek. We therefore hold that petitioners have standing to challenge the EPA's denial of their rulemaking petition. ${ }^{98}$

On the merits, the Court then held that the EPA had misapplied the Clean Air Act in several critical respects, ${ }^{99}$ remanding for further consideration by the agency under the correct statutory standards.

96. Id.

97. Id. at 1458 .

98. Id. The reliance on the plaintiffs' affidavits reflects an ambiguity in the opinion-usually the Court's statements about climate change are framed as judicial notice of scientific fact, but here the Court merely recited the litigants' assertions.

99. The EPA had argued that carbon dioxide is not a pollutant within the meaning of the Clean Air Act. The Court found this view incompatible with the plain language of the statute:

The statutory text forecloses [the] EPA's reading. The Clean Air Act's sweeping definition of "air pollutant" includes "any air pollution agent or combination of such agents, including any physical, chemical ... substance or matter which is emitted into or otherwise enters the ambient air ...." $\$ 7602(\mathrm{~g})$ (emphasis added). On its face, the definition embraces all airborne compounds of whatever stripe, and underscores that intent through the repeated use of the word "any." Carbon dioxide, methane, nitrous oxide, and hydrofluorocarbons are without a doubt "physical [and] chemical ... substance[s] which [are] emitted into ... the ambient air." The statute is unambiguous.

Id. at 1460 (internal footnote omitted). The Court also found that the EPA had considered impermissible extraneous factors in making its determination:

Although we have neither the expertise nor the authority to evaluate these policy judgments, it is evident they have nothing to do with whether greenhouse gas emissions contribute to climate change. Still less do they amount to a reasoned justification for declining to form a scientific judgment. In particular, while the President has broad authority in foreign affairs, that authority does not extend to the refusal to execute domestic laws. Id. at 1463. 


\section{The Gospel According to Roberts}

Chief Justice Roberts wrote a vigorous dissent on the standing issue, which was joined by Justices Scalia, Thomas, and Alito. ${ }^{100}$ The dissent had four major disagreements with the majority.

First, the dissent rejected the view that states are entitled to special solicitude in terms of their standing claims and challenged the majority's assertion of precedential support for this idea. As the dissent pointed out, however, it is unclear whether this special solicitude really affected the outcome in Massachusetts, since the majority also found that the normal three-part test for standing had been satisfied. ${ }^{101}$

Second, the dissent could find no particularized injury in fact. In the dissent's view, the "very concept of global warming seems inconsistent with this particularization requirement," since climate change affects the entire human race. ${ }^{102}$ After all, the dissent observed, "the redress petitioners seek is focused no more on them than on the public generally-it is literally to change the atmosphere around the world." ${ }^{103}$ As to the claim that the particularized injury was loss of coast land, that claim failed to meet the demand that injury be "actual or imminent, not conjectural or hypothetical, real and immediate, and certainly impending." 104 The dissent could find "nothing in petitioners' 43 standing declarations and accompanying exhibits to support an inference of actual loss of Massachusetts coastal land from 20th century global sea level increases." ${ }^{105}$ Longer-term injury was alleged in

100. Fundamentally, the dissent contended, the majority had subtly distorted the application of the standing test:

The Court's sleight-of-hand is in failing to link up the different elements of the threepart standing test. What must be likely to be redressed is the particular injury in fact. The injury the Court looks to is the asserted loss of land. The Court contends that regulating domestic motor vehicle emissions will reduce carbon dioxide in the atmosphere, and therefore redress Massachusetts's injury. But even if regulation does reduce emissions- to some indeterminate degree, given events elsewhere in the world-the Court never explains why that makes it likely that the injury in fact-the loss of land-will be redressed. Schoolchildren know that a kingdom might be lost "all for the want of a horseshoe nail," but "likely" redressability is a different matter. The realities make it pure conjecture to suppose that EPA regulation of new automobile emissions will likely prevent the loss of Massachusetts coastal land.

Id. at 1470 (Roberts, C.J., dissenting).

101. Id. at 1466.

102. Id. at 1467.

103. Id. Justice Roberts seems to have overlooked the fact that climate change will have differential impacts in different locations. For example, only coastal areas will lose land as a direct result of sea level change.

104. Id. (internal quotation marks and citations omitted).

105. Id. 
the affidavits, but "accepting a century-long time horizon and a series of compounded estimates renders requirements of imminence and immediacy utterly toothless." ${ }^{106}$

Third, the dissent argued, the Court had misapplied the causation requirement. In the dissent's view, the majority opinion "ignores the complexities of global warming, and does so by now disregarding the "particularized' injury it relied on in step one, and using the dire nature of global warming itself as a bootstrap for finding causation and redressability." ${ }^{107}$ Because the case involved only new vehicles sold in America, the case would affect "only a fraction of 4 percent of global emissions."108 Furthermore, according to Chief Justice Roberts, predicting future climate change involves a complex web of economic and physical factors, and the plaintiffs "are never able to trace their alleged injuries back through this complex web to the fractional amount of global emissions that might have been limited with EPA standards." 109

Furthermore, "[r]edressability [was] even more problematic"110 in the dissent's view. Because of projected emissions from China and India, "the domestic emissions at issue here may become an increasingly marginal portion of global emissions, and any decreases produced by petitioners' desired standards are likely to be overwhelmed many times over by emissions increases elsewhere in the world." Given the dissent's view that a reduction in domestic emissions would have a trivial impact on global climate change, the redressability of environmental harms seemed untenable. The dissent contended that "the Court never explains why [a reduction in domestic emissions] makes it likely that the injury in fact-the loss of land-will be redressed."112

Finally, the dissent stressed what it viewed as the constitutional imperatives underlying standing law. Admittedly, when "dealing with legal doctrine phrased in terms of what is 'fairly' traceable or 'likely' to be redressed, it is perhaps not surprising that the matter is subject to some

106. Id. at 1468 .

107. Id.

108. Id. at 1469.

109. Id.

110. Id.

111. Id. This claim is a common argument in climate change debates, but it is mistaken to think that U.S. emissions will have no significant effect even if other emissions are not controlled. See Daniel A. Farber, The Case for Climate Compensation: Doing Justice in a Complex World, UTAH L. REV. (forthcoming).

112. Massachusetts, 127 S. Ct. at 1470 (Roberts, C.J., dissenting). 
debate."113 Nevertheless, the Chief Justice said, "in considering how loosely or rigorously to define those adverbs, it is vital to keep in mind the purpose of the inquiry" because the "limitation of the judicial power to cases and controversies 'is crucial in maintaining the tripartite allocation of power set forth in the Constitution."'14 This emphasis on the separation of powers implications of standing resonates with Justice Scalia's efforts to refocus standing doctrine, but it is telling that the Chief Justice mentioned these concerns only in passing and even more telling that he spoke only for a minority of the Court.

The sweep of Chief Justice Roberts's dissent is unclear. Some of his language would suggest that no plaintiff could ever have standing to litigate climate change issues because of the planetary impact of climate change and its long time scale. This position, if it were to command a majority of the Court, would be a serious problem if Congress adopts climate change regulations. Judicial review would be open only to regulated interests rather than to affected members of the public, unbalancing the statute's administration. But the Chief Justice may not have meant to go so far.

Much of the Roberts dissent is quite factually oriented and may leave open the possibility that the Chief Justice would be willing to find standing with a more developed factual record. It is plausible that in future cases a plaintiff might be able to more firmly establish current impacts from climate change as well as the need for immediate investments to cope with more long-range effects. For example, the projected extent of climate change is an element that must be considered in planning the construction of long-lived infrastructure, showing that the potential for future climate change has a tangible immediate impact on the state's activities. Also, computer modeling may make it possible to disaggregate the effects of climate change, showing just how much a given governmental policy might contribute to harm (with or without third-party efforts to control climate change).

To the extent that such evidence is persuasive to the Chief Justice, his vote in future climate change cases might depend not only on his willingness to follow Massachusetts as a precedent but also on developments in climate

113. Id.

114. Id. (internal quotation marks omitted). Prior to his appointment, Chief Justice Roberts had written an article arguing that the injury requirement is necessary to keep the courts within their prescribed role in the separation of powers. See John G. Roberts, Jr., Arricle III Limits on Statutory Standing, 42 DUKE L.J. 1219 (1993). The article's core argument seems to be that a generalized desire to enforce the law should not be a basis for invoking the powers of the courts. But apart from precedent, he did not offer any justification for why "injury" should be the defining basis for judicial action. To some extent the place-based approach developed in infra Part IV might satisfy his desire for some demarcation of the limits of judicial authority. 
modeling and scientific knowledge. If Congress passes climate change regulations, it would seem odd to give industry but not environmental interests the ability to seek judicial review-perhaps odd enough to strike the Chief Justice as unfair. In light of this possibility, it may well be a mistake to give up on him or some of the other dissenting justices as future votes in support of climate standing.

\section{THE WEAKNESS OF CURRENT APPROACHES}

Chief Justice Roberts's dissent invoked the separation of powers argument for restricting standing. It also took the injury-in-fact requirement and its corollaries of causation and remediability very seriously, rather as if the plaintiffs were bringing a tort case and seeking to recover damages for climate change effects. ${ }^{115}$ These aspects of his dissent are connected; the separation of powers argument suggests limiting courts to the most traditional forms of litigation lest they intrude on executive prerogatives. This Part will show, however, that the separation of powers argument is tenuous. And the injury-in-fact requirement, a relatively recent judicial creation with weak roots in constitutional history, is hardly deserving of the totemic significance it received in the Roberts opinion.

\section{A. The Separation of Powers Argument}

To understand just how much ideas of standing have changed in the past two decades, we can contrast Lujan $v$. Defenders of Wildlife ${ }^{116}$ with the position taken in the government's brief in Sierra Club $v$. Morton. ${ }^{117}$ The language is startlingly at odds with what we are accustomed to hearing today from advocates for the executive branch:

Here, although it apparently might have claimed a more traditional basis for standing, petitioner based its claim only on a statute declaring an undifferentiated "public" interest, in this case an interest in the preservation of certain types of values in designated public lands.... While Congress has undoubted power to authorize such litigation ... in the absence of such authorization the undifferentiated

115. The elements of the current standing test are rather reminiscent of tort law: duty toward the plaintiff, causation, proximate cause, and damages. It is unclear, however, why anyone would think that the elements of tort law have constitutional status via Article III's definition of "case or controversy."

116. 504 U.S. 555 (1992).

117. 405 U.S. $727(1972)$. 
public interest in assuring that park and forest administrators obey governing statutes is insufficient to establish standing to sue. ${ }^{118}$

Indeed, the Sierra Club Court seems to have shared the Solicitor General's view that Congress could freely grant standing. A footnote to the opinion states that Congress may not authorize advisory opinions or friendly suits, but that "where a dispute is otherwise justiciable, the question whether the litigant is a 'proper party to request an adjudication of a particular issue,' is one within the power of Congress to determine."19 By the time of Defenders of Wildlife, this ready acceptance of congressional power had gone out the window, as part of a general shift toward more stringent requirements for standing.

Much of the credit for this shift belongs to Justice Scalia. In an article written before he joined the Court, Scalia had argued that the standing doctrine played a critical role in protecting executive discretion from judicial interference. ${ }^{120}$ He complained that litigation by citizen groups could force the executive branch toward "adherence to legislative policies that the political process itself would not enforce." ${ }^{\text {"121 }}$ Expanded standing undercut the executive's "ability to lose or misdirect laws," which he considered "one of the prime engines of social change." 122 He found standing doctrine to be poorly designed for its ostensible purpose of assuring "that concrete adverseness which sharpens the presentation of issues."123 Instead, he contended that it does have merit because it "roughly restricts courts to their traditional undemocratic role of protecting individuals against impositions of the majority, and excludes them from the even more undemocratic role of prescribing how the other two branches should function in order to serve the interest of the majority itself." courts should protect only minority interests (such as those of regulated parties) rather than broadly diffused groups (such as everyone who breathes polluted air).

To serve this function of protecting minority interests, Scalia argued standing law must require the plaintiff to show "some respect in which he is

118. Brief for the Respondent at 17, Sierra Club v. Morton, 405 U.S. 727 (1972) (No. 70-34) (emphasis added) (footnote omitted).

119. Sierra Club, 405 U.S. at 732 n.3 (citation omitted).

120. Antonin Scalia, The Doctrine of Standing as an Essential Element of the Separation of Powers, 17 SUFFOLK U. L. REV. 881 (1983).

121. Id. at 896 .

122. Id. at 897 .

123. Id. at 891 .

124. Id. at 894 . It is not clear why protecting the majority from lawless public servants should be considered undemocratic. 
harmed more than the rest of us."125 Thus, he said, an injury might be "so widely shared that a congressional specification that the statute at issue was meant to preclude precisely that injury would nevertheless not suffice to mark out a subgroup of the body politic requiring judicial protection." ${ }^{126}$ Scalia was unfazed by the possibility that this approach to standing would allow important legislative purposes to die in the halls of the executive branch. Indeed, he found particular value in such a result: "Where no peculiar harm to particular individuals or minorities is in question, lots of once-heralded programs ought to get lost or misdirected, in vast hallways or elsewhere." ${ }^{127}$

After joining the Court, Justice Scalia suggested that this view of standing is linked to Article II of the Constitution. As he said in Defenders of Wildlife, "[t]o permit Congress to convert the undifferentiated public interest in executive officers' compliance with the law into an 'individual right' vindicable in the courts is to permit Congress to transfer from the President to the courts the Chief Executive's most important constitutional duty, to 'take Care that the Laws be faithfully executed." ${ }^{128}$ He thus seemed to shift the constitutional basis for standing doctrine from Article III to Article II.

This theory was also reflected in Justice Scalia's Laidlaw dissent. He began by recalling the Article II directive that the president "take Care that the Laws be faithfully executed." Citizen suits, which in essence create a mechanism for law enforcement by private attorneys general, might be suspect as impinging on presidential control of the enforcement process. Justice Scalia at least hinted at this sort of challenge to citizen-suit statutes. Although he did not directly address whether citizen suits violate Article II, he pointed out that "Article III, no less than Article II, has consequences for the structure of our government, and it is worth noting the changes in that structure which today's decision allows." 129

Justice Scalia emphasized that by "[b]y permitting citizens to pursue civil penalties payable to the Federal Treasury, the [Clean Water] Act does not provide a mechanism for individual relief in any traditional sense, but turns over to private citizens the function of enforcing the law." ${ }^{, 130} \mathrm{He}$ added that a "Clean Water Act plaintiff pursuing civil penalties acts as

125. Id.

126. Id. at $895-96$.

127. Id. at 897 .

128. Lujan v. Defenders of Wildlife, 504 U.S. 555, 577 (1992).

129. Friends of the Earth v. Laidlaw Envtl. Servs. (TOC), Inc., 528 U.S. 167, 209 (2000) (Scalia, J., dissenting).

130. Id. 
a self-appointed mini-EPA." He lamented this incursion on the executive's discretion to turn a blind eye to violations of law:

Elected officials are entirely deprived of their discretion to decide that a given violation should not be the object of suit at all, or that the enforcement decision should be postponed. This is the predictable and inevitable consequence of the Court's allowing the use of public remedies for private wrongs. ${ }^{131}$

Thus, while eschewing direct reliance on Article II, Justice Scalia's Laidlaw dissent tracks his Article II-based argument made in Defenders of Wildlife and in his earlier law review article. ${ }^{132}$

There is a certain irony to Justice Scalia's invocation of the Article II "take care" clause. Citizen-suit laws are not relevant to situations in which a president is seeking to enforce the law over congressional objections. Rather, these statutes are designed for situations in which the president or his delegates prefer not to faithfully execute a law, finding it disagreeable to follow the law or to require private parties to do so. A cynic might say that Justice Scalia had rewritten the clause to require the president to "take care that the Law be fitfully executed."

Justice Scalia's argument for restricting standing is part and parcel of his more general argument for expanded presidential power, in this case to encompass the power to change public policy through deliberate nonenforcement of law. Although Justice Scalia is a staunch originalist, he has never made a serious effort to provide a historical grounding for his general view of presidential power-his opinions notably lack any detailed historical analysis of Article II. The closest he has come was a sketch of the evidence that he said "might have been used" to support the argument for broad presidential power:

[T]he traditional English understanding of executive power, or, to be more precise, royal prerogatives, was fairly well known to the founding

131. Id. at 210 (citation omitted).

132. Justice Scalia's theory about standing has a complex relationship with his approach to the Chevron doctrine. See Chevron, U.S.A., Inc. v. NRDC, 467 U.S. 837 (1984) (noting that courts must defer to an agency interpretation when the statutory language and legislative history are unclear and the agency has adopted a reasonable interpretation). That doctrine requires courts to defer to administrative interpretations of ambiguous statutes. As Professor Anne Joseph O'Connell once pointed out to me, Justice Scalia tends to find statutory language clear and leaves no room for agency discretion, whereas his standing theory would suggest that agencies should have considerable leeway to stretch statutory language, particularly when doing so reduces regulatory scope and therefore retreats from congressional goals. Yet, Justice Scalia's standing theory resonates with another aspect of his approach to statutory interpretation. He has resisted contraction of Cheuron's domain and instead emphasized executive power to resolve statutory ambiguities as a means of combating statutory ossification. See United States v. Mead Corp., 533 U.S. 218, 247 (2001) (Scalia, J., dissenting). 
generation, since they appear repeatedly in the text of the Constitution in formulations very similar to those found in Blackstone. It can further be argued that when those prerogatives were to be reallocated in whole or part to other branches of government, or were to be limited in some other way, the Constitution generally did so expressly. One could reasonably infer, therefore, that what was not expressly reassigned would-at least absent patent incompatibility with republican principles-remain with the executive. ${ }^{133}$

Justice Scalia's words posit the English monarchy as the model for the American presidency. Perhaps so, but as Justice Scalia admitted, the historical record is also replete with evidence that "many in the founding generation" were still repelled by the notion of using the English monarchy as a guidepost for executive power. ${ }^{134}$ In any event, one would expect an originalist with a strong interest in issues of executive power to have attempted a more thorough investigation of the historical evidence, especially given this discrepancy.

Scalia's general view of presidential power is at odds with much of mainstream historical scholarship. Conventional wisdom on the subject of executive power was aptly expressed by conservative legal scholar Henry Monaghan, a staunch originalist. ${ }^{135}$ According to Monaghan, the "transformation of the Constitution of 1789 is seen nowhere more clearly than in the modern Presidency." ${ }^{136}$ Monaghan finds the contemporary conception of the presidency unsupported by the intent of the Framers, for "the President today plays a dominant role in the national government completely beyond the understanding in 1789."137 Similarly, Cass Sunstein has said, "the alleged constitutional commitment to a strongly unitary executive-a president who was to be in charge of all of what we now call implementation of the law-seems ... to have been greatly oversold." ${ }^{138}$ It would be surprising if

133. Antonin Scalia, Originalism: The Lesser Evil, 57 U. CIN. L. REV. 849, 859-60 (1989). Why, one wonders, are only patent inconsistencies with republican principles sufficient to curb executive power? Why not less obvious but nonetheless real inconsistencies?

134. Id. at 858 .

135. Henry Paul Monaghan, Stare Decisis and Constitutional Adjudication, 88 COLUM. L. REV. 723, 736 (1988). For a debate about the correct reading of the historical record, see Lawrence Lessig \& Cass R. Sunstein, The President and the Administration, 94 CoLUM. L. REV. 1 (1994); Steven G. Calabresi \& Saikrishna B. Prakash, The President's Power to Execute the Laws, 104 YALE L.J. 541 (1994).

136. Monaghan, supra note 135 , at 736.

137. Id.

138. Cass R. Sunstein, Article II Revisionism, 92 MiCH. L. REv. 131, 135 (1993). As Sunstein pointed out,

In fact, [the Framers] allowed Congress considerable power to structure implementation as it saw fit. We know, for example, that in the period after the Founding, much prosecution under federal law took place without presidential control. Neither the 
the historical record provided an unambiguous portrait of the Framers' understanding of executive power, but the record does not even nominally support some modern visions of presidential omnipotence.

Justice Scalia's core notion in his writings about standing is that the executive should have leeway to exercise benign neglect in enforcement, thereby leaving statutory mandates to wither. There are sound grounds for thinking that this notion was repugnant to the Framers. ${ }^{139}$ They were not unfamiliar with executive claims of the power to limit legislation through refusal to enforce it. King James II had attempted to use such a "dispensing power" to suspend enforcement of laws he disliked, reviving an executive practice that had already been held illegal in Britain in 1662 and 1672..$^{140}$ Shortly thereafter, he was forced off the throne by the Glorious Revolution. ${ }^{141}$ There is no reason to believe the Framers would have embraced Justice Scalia's effort to revive King James's dispensing power via the law of standing. If anything, the take care clause is an explicit repudiation of such executive power.

Justice Scalia's failure to do any real historical spade work on Article II, an issue so central to his constitutional vision, may indicate a certain inconstancy in his concern for original intent. We will see in the next section that he has been equally remiss in failing to investigate the historical record to determine whether the original understanding of the judicial function required an individuated injury. Putting aside originalist concerns, the use of litigation to discipline the implementation of statutes seems central to the modern administrative state, at least in its American incarnation. In attempting to subordinate judicial enforcement of statutory mandates to political bargaining between the president and Congress, Justice Scalia's theory seems inconsistent with the tenor of administrative law. His desire to limit standing to regulated parties or other small groups with discrete private interests is at odds with Sierra Club and its grant of standing to diffuse groups with interests that are shared by many members of the public.

President nor the Attorney General controlled the district attorneys. Citizens could enforce federal law in state court. Moreover, both the Comptroller General and the Postmaster Id. were immunized from the general control of the President.

139. If the president is constitutionally entitled to forgive violations of law by refusing to prosecute, and if (as Justice Scalia and others insist) he has control of all law enforcement, then it is hard to see why he needs the pardon power.

140. See 2 SimOn SChama, A History Of Britain: THE British Wars 1603-1776, at $308(2001)$.

141. Id. at 317-18. 
The Supreme Court clearly does not accept Justice Scalia's theory of standing based on executive discretion or his corollary that what otherwise would constitute injury in fact ceases to be so when it is broadly shared. Federal Election Commission v. Akins ${ }^{142}$ dealt the decisive blow to Justice Scalia's theory of standing. In Akins, the plaintiffs challenged the election commission's failure to require a lobbying group to disclose information. The Court found that the plaintiffs had suffered injury in fact in the form of "their inability to obtain information" that the statute required the group to make public, despite the fact that the right to this information was shared by every member of the public. ${ }^{143}$ The Court also held that the redressability prong was satisfied even though the commission retained discretion over whether to regulate. ${ }^{144}$

The implications of Akins can be seen in American Canoe Ass'n v. City of Louisa Water $\mathcal{F}^{2}$ Sewer Commission. ${ }^{145}$ The Sixth Circuit granted standing to the American Canoe Association and the Sierra Club to sue the commission for failure to monitor and to report pollution discharges. This failure caused informational injury to both organizations by denying them information that is required to be made public under the Clean Water Act. In explaining why this is not the sort of "generalized grievance" that would be outside of judicial cognizance, the court explained:

$[T]$ he injury alleged is not that the defendants are merely failing to obey the law, it is that they are disobeying the law in failing to provide information that the plaintiffs desire and allegedly need. This is all that plaintiffs should have to allege to demonstrate informational standing where Congress has provided a broad right of action to vindicate that informational right. ${ }^{146}$

Information by its nature is a public good, equally accessible and usable by all once it has been made public. Nevertheless, Atkins illustrates that a desire for the information is enough to create standing. The notion of informational standing is clearly inconsistent with Justice Scalia's concept of standing. Massachusetts v. EPA eliminated any possible remaining doubts about the demise of Justice Scalia's standing theory. Even an action that injures everyone does not eliminate standing for an individual plaintiff-the Massachusetts Court found standing even though climate

142. 524 U.S. 11 (1998).

143. Id. at 21 .

144. Id. at 24-26.

145. 389 F.3d 536 (6th Cir. 2004).

146. Id. at 546 . 
change affects everyone on the planet. That my neighbor would also have standing does not eliminate my own standing.

The fundamental concept underlying the Scalian theory of standing is that the executive branch has broad discretion to kill regulatory programs through inaction. In its discussion of the merits in Massachusetts v. EPA, the Court also made clear its rejection of this vision of administrative law. The Court agreed that the EPA had "significant latitude as to the manner, timing, content, and coordination of its regulations with those of other agencies. ${ }^{147}$ Yet, the Court continued,

once EPA has responded to a petition for rulemaking, its reasons for action or inaction must conform to the authorizing statute. Under the clear terms of the Clean Air Act, EPA can avoid taking further action only if it determines that greenhouse gases do not contribute to climate change or if it provides some reasonable explanation as to why it cannot or will not exercise its discretion to determine whether they do. To the extent that this constrains agency discretion to pursue other priorities of the Administrator or the President, this is the congressional design. ${ }^{148}$

Rejecting the EPA's argument that it could consider any factor it deemed relevant in determining whether to regulate, including foreign policy and other considerations, ${ }^{149}$ the Court make clear its view that the "EPA must ground its reasons for action or inaction in the statute."150 Thus, the Court firmly rejected the view that the administration may justify ignoring a statutory mandate on the basis that it disagrees with the governing law and prefers another regulatory approach.

The Court was surely correct that statutory mandates cannot be ignored simply because the executive branch has an alternate policy view. There is an important constitutional principle at stake here, but it is not the one that Justice Scalia has invoked. Instead, it is the supremacy of Congress over regulatory policy. Article I of the Constitution vests Congress with legislative

147. Massachusetts v. EPA, 127 S. Ct. 1438, 1462 (2007).

148. Id.

149. The Court noted:

[The] EPA has refused to comply with this clear statutory command. Instead, it has offered a laundry list of reasons not to regulate. For example, EPA said that a number of voluntary executive branch programs already provide an effective response to the threat of global warming, that regulating greenhouse gases might impair the President's ability to negotiate with "key developing nations" to reduce emissions, and that curtailing motor-vehicle emissions would reflect "an inefficient, piecemeal approach to address the climate change issue" ....

Id. at 1462-63 (citations omitted).

150. Id. at 1463. 
power and provides only one method for repealing those laws: bicameral passage and presidential review. Enacted statutes constitute what Article VI calls the "supreme law of the land." The Constitution explicitly requires the president to take care that the laws-all the laws-be faithfully executed. Whatever arguments can be made for limitations on standing, one argument cannot possibly be correct-that restricting standing is desirable because it gives the president more leeway to disregard the law. ${ }^{151}$ This flawed argument serves as the lynchpin of Justice Scalia's theory of standing, and it is fortunate that the Court has rejected it.

Once we put aside this misguided effort to deploy Article II in the service of restricting standing, we can turn our attention to the true issue, which is simply the best way to interpret Article III's requirement of a "case or controversy." Current standing doctrine relies on the concept of injury in fact to answer this question. It is important to recognize, however, that this concept is not written in stone as part of the constitutional design. Instead, it is merely a judicial effort to operationalize the notion of a personal connection between the plaintiff and the lawsuit.

\section{B. Injury in Fact and Its Discontents}

Because the current test for standing is so familiar, there may be a tendency to view it as sacrosanct in all of its details. This would be a mistake. There are two sound criticisms of current standing doctrine. First, it requires a great deal of judicial effort, but has an unpredictable effect in limiting the kinds of claims brought before the Court. Second, it has dubious historical roots, a matter that should particularly concern originalists.

\section{Standing Doctrine as a Large Judicial Investment With Haphazard Results}

A great deal of judicial effort goes into determining standing. Massachusetts $v$. EPA exemplifies the situation; the discussion of standing by the Court and dissent takes up roughly as much space as the discussion of the merits. Lower court cases devote a similar degree of attention to the issue. ${ }^{152}$

151. A more modest theory is that the president should have the ability to interpret the laws and hence to refuse enforcement when he believes the law is inapplicable. The Chevron doctrine, which mandates judicial deference to the executive's interpretations of statutes, seems to provide adequate protection to this executive prerogative without the need to impose artificial restrictions on standing.

152. See, e.g., Main People's Alliance v. Mallinckrodt, Inc., 471 F.3d 277, 285 (1st Cir. 2006) (finding standing after an extensive discussion, on the basis of expert testimony that the court 
Under current doctrine, courts are required to address potentially difficult standing issues even if the case could easily be disposed of on the merits, thus increasing their workload. ${ }^{153}$

One indication of the burdens created by the current standing approach is the number of court of appeals opinions using the phrase "standing to sue" -3742 according to a recent Westlaw search. ${ }^{154}$ Current standing doctrine clearly requires enormous judicial effort to implement, yet this is a desirable state of affairs.

Judge Patricia Wald once poignantly questioned whether this was judicial time well spent:

I ask you: Is this work for sophisticared adult jurists?... More than most subjects of lawsuits, the use of our natural resources is a communitarian matter. Why then must a genuine dispute over an acknowledged injury to the environment stemming from a violation of law be judgeable only when one individual can show a minutely particularized use of the resource that is threatened, down to the last square inch of hiked soil, or the date of the next planned visit to the zoo? I believe it is truly time to reconceptualize environmental standing. Whether our substantive environmental law changes or remains the same, surely the incorporation into our law of more realistic notions of which affected persons or communities have the right to protest environmental violations is subject to rethinking. ${ }^{155}$

paraphrased as saying, "in effect, that the presence of a great deal of smoke justified looking for a fire"); Ecological Rights Found. v. Pac. Lumber Co., 230 F.3d 1141 (9th Cir. 2000) (considering carefully the degree of past recreational use, combined with possible residential proximity, needed to establish standing); Humane Soc'y v. Babbitt, 46 F.3d 93 (D.C. Cir. 1995) (analyzing painstakingly whether an organization or its members had standing to challenge the transfer of an elephant as a possible violation of the Endangered Species Act); Nat. Res. Defense Council v. EPA, 464 F.3d 1, 7 (D.C. Cir. 2006) (deciding on rehearing that an increased lifetime risk of about 1 in 200,000 of skin cancer was enough to justify standing). Some additional lower court opinions are cited supra Part II.

153. Steel Co. v. Citizens for a Better Env't, 523 U.S. 83, 97 n.2 (1998) (finding that courts must always address standing prior to addressing the merits).

154. Westlaw search, Apr. 2, 2008, for "standing to sue" of federal appeals courts and Federal Circuit databases.

155. Patricia Wald, Envirommental Postcards From the Edge: The Year That Was and the Year That Might Be, 26 ENVTL. L. REP. 10182 (1996). More recently, the D.C. Circuit seems to have launched a campaign to quantify risks in order to determine the presence of standing, leading to, at least in one notable case, embarrassing mathematical errors. See Cassandra Sturkie \& Nathan H. Seltzer, Developments in the D.C. Circuit's Article III Standing Analysis: When Is an Increased Risk of Future Harm Sufficient to Constitute Injury-in-Fact in Environmental Cases?, 37 ENVTL. L. REP. 10287 (2007). Fortunately, the place-based approach in this Article would free judges from the awkwardness of performing mathematical calculations in order to determine the limits of federal jurisdiction. 
The Court's efforts to distinguish between injuries in fact and other grievances have often been unconvincing, prompting a leading scholar on federal jurisdiction to complain that "[d]istinctions such as this are too thin to carry much credibility." 156 When a doctrine requires great effort to apply and even then fails to produce convincing decisions, some rethinking seems to be in order.

The substantial amount of investment in determining standing would perhaps be worthwhile if standing law successfully filtered out claims that were not suitable for judicial resolution on the merits. However, the injuryin-fact requirement accomplishes this only fitfully at best. Failure to establish standing does not generally reflect some fundamental unsuitability of a claim for judicial resolution, but rather might indicate failure to file the correct affidavits or to identify and to enlist unconventional plaintiffs. Indeed, in most of the cases in which the Court has declined to find standing or where standing was hotly disputed, alternative standing theories were readily available and could have been easily satisfied. ${ }^{157}$ In some cases, such as Lujan ข. National Wildlife Federation, ${ }^{158}$ it is quite likely that the same plaintiffs could have satisfied the standing requirement merely by redrafting their affidavits (in that case, to avoid the use of the apparently fatal word "near," which the Court found to be an insufficient indication of proximity to support a claim of injury). Alternatively, the plaintiffs might well have been able to show that increased coal mining would increase fugitive dust from mines or conventional pollution from transportation of the coal, or produce other geographically widespread harms, which would have constituted injury in fact for anyone in the general vicinity of the activities.

Likewise, in Massachusetts v. EPA, the plaintiffs probably could have satisfied standing requirements without confronting the Chief Justice's doubts about the effects and redressability of climate change. A simple alternate theory of standing could likely have served instead. If the EPA regulates carbon dioxide as a greenhouse gas, any feasible method of reducing automobile emissions will necessarily entail decreased use of gasoline. ${ }^{159}$ It is impossible to remove carbon dioxide directly from tailpipe emissions, so the amount produced in combustion has to equal the amount of carbon in

156. Richard H. Fallon, Jr., The Linkage Between Justiciability and Remedies-And Their Connections to Substantive Rights, 92 VA. L. REV. 633, 664 (2006).

157. For instance, in Bennett v. Spear, 520 U.S. 154, 161-62 (1996), the Court upheld a "zone of interests" requirement, despite the lack of constitutional basis.

158. 497 U.S. 871 (1990).

159. See Arnold W. Reitze Jr., Controlling Greenhouse Gas Emissions From Mobile Sources: Massachusetts v. EPA, 37 ENVTL. L. REP. 10535, 10538 (2007). 
the fuel. The probable effect of reducing the amount of fuel burned would be to reduce the quantity of other automobile emissions from burning gasoline. ${ }^{160}$ Hence, roughly the same people should have standing in the Massachusetts ${ }^{161}$ case as in any case involving nationwide regulation of pollution sources-people forced to breathe automobile pollution, particularly people prone to respiratory disease such as children, asthmatics, and the elderly. They would need only to allege that failure to impose restrictions on greenhouse gases would have a detrimental impact on their health. The EPA's failure to issue regulations to decrease automobile emissions causes injury in fact to these plaintiffs in a straightforward way.

This standing theory for climate litigation parallels that of Duke Power. ${ }^{162}$ There, the plaintiffs used minor but immediate environmental impacts as a basis for standing to raise claims concerning potential long-term and quite contingent harms. Similarly, the plaintiffs could have drawn on the immediate health impacts of gasoline use as a basis for standing to raise the same claims. But what is the point served by requiring the plaintiffs to recast their complaint in these terms?

Article III standing would also be found in a climate change case brought by automobile companies with low emission cars; these companies would obtain a competitive advantage from an EPA rule limiting emissions. Thus, even adopting a restrictive view of standing would keep climate change cases out of court only so long as the automobile industry chose to retain a united front. It seems peculiar to think that whether the federal courts can consider a certain class of issues depends on the degree to which an industry is able to maintain solidarity.

Clever lawyers could find other ways to bring environmental claims, even if standing were limited to cases involving economic or physical injuries to discrete groups. Business interests often would have Article III standing to raise environmental claims, so standing restrictions would merely serve to prevent the same claims when brought by those representing the

160. The reason for the qualification ("probable") is that there might be offsetting behavioral changes-the lower price of fuel per mile driven might lead to an increase in miles driven, and over time, decreased pollution from automobiles might be offset by increases in pollution from other sources (keeping within the ceilings imposed by other sections of the Clean Air Act). See Linda Baker, On the Rebound: Discouraging People From Using More Energy Just Because It Costs Less, SCI. AM., Aug. 2007, at 24, 24. The possibility of a complete offset, however, does not seem so great as to defeat a claim of standing. Note that the plaintiff may not have wanted to pursue this theory of standing for fear that it would reinforce the defendant's arguments that the standards governing automobile mileage took precedence over the EPA's regulatory jurisdiction for carbon dioxide.

161. Massachusetts v. EPA, 127 S. Ct. 1438 (2007).

162. Duke Power v. Carolina Environmental Study Group, Inc., 438 U.S. 59 (1978). 
environment. For example, in National Wildlife Foundation, companies in industries with competing fuel sources would have Article III standing to challenge the coal leasing program--increased coal availability would diminish the market for natural gas and hydropower. In SCRAP, the most obvious plaintiffs were scrap recyclers, whose standing as shippers was beyond question since the ICC's order increased the fees they paid for shipments. Alternatively, consumers could have argued that the price of recycled materials had risen or that such materials were hard to obtain. Expert testimony by economists could have reinforced the principle that higher costs are reflected in lower output and higher prices. ${ }^{163}$ So even in a world of highly restricted standing, it would be possible for courts to be confronted with exactly the same legal claims brought by other parties. But there does not seem to be a good reason why members of the public should have to rely on the happenstance of assistance from interested business groups in order to obtain the enforcement of environmental laws.

In short, government regulatory actions will often create the requisite injury in fact, although in a given case an environmental organization may not be able to recruit the appropriate plaintiff or may have strategic reasons for avoiding an otherwise tenable standing argument. ${ }^{164}$ As science advances, our ability to identify the causal mechanisms of increased levels of risk to health or the environment (and consequently our ability to identify injuries in fact) continually increases, leaving fewer cases outside of the ambit of standing. ${ }^{165}$ The injury-in-fact requirement is a haphazard way of limiting which claims can be heard and which plaintiffs can bring them. No doubt it does limit litigation by plaintiffs who are ideologically motivated because it requires them to do more work prior to filing suit. Whether limiting litigation should be a goal of the courts is debatable, but if it is their goal, the intricacies of standing doctrine are a peculiar way of reaching it. For instance, a higher filing fee would have the same effect in deterring litigation by public interest groups and would require much less judicial effort to enforce. Unlike

163. The point is not to fault the plaintiffs for failing to make this argument-they would no doubt have run into zone-of-interest problems in terms of their environmental claims. But the reality of their injury thus presented could hardly be denied. Thus, the injury-in-fact requirement presents genuine procedural challenges to plaintiffs but does nothing in principle to keep the courts free from certain kinds of claims.

164. Or the organization might need help from Congress in eliminating the statutory zone-ofinterest requirement, which itself has no Article III foundation.

165. See Robin Kundis Craig, Removing "The Clock of a Standing Inquiry": Pollution Regulation, Public Health, and Private Risk in the Injury-in-Fact Analysis, 29 CARDOZO L. REV. 149 (2007) (advocating greater use of risk analysis as a basis for standing). 
suitors in fairy tales, public interest organizations should not be required to climb glass mountains or slay dragons in order to receive their reward.

\section{A Dubious Constitutional Foundation}

Some commentators argue strenuously that the Court took a wrong step in Sierra $\mathrm{Clu} b^{166}$ by requiring injury in fact, rather than focusing on whether Congress had created a cause of action. Cass Sunstein argues that the test should be "whether the plaintiffs interest was protected by the underlying substantive statute" 167 or more generally that the "existence of standing and the existence of a cause of action present the same basic question."168 Sunstein contends that the injury-in-fact test is a "revisionist view of Article III, with no textual or historical support." ${ }^{169}$ He musters considerable historical evidence, showing that the prerogative writs of prohibition and certiorari were available to citizens generally, without any need to show special injury, in both English law and early American law. The same may also have been true of the writs of mandamus and quo warranto. ${ }^{170}$ Moreover, informer and qui tam actions were very well established. ${ }^{171}$

Sunstein searches for the source of the injury-in-fact test, but to no avail: "Did the Supreme Court just make it up? The answer is basically yes." ${ }^{172}$ One might have thought that this lack of historical support would be troubling for a purported originalist such as Justice Scalia. In any event, there

166. Sierra Club v. Morton, 405 U.S. 727 (1972).

167. Cass R. Sunstein, Standing and the Privatization of Public Law, 88 COLUM. L. REV. 1432, 1462 (1988); see also F. Andrew Hessick, Standing, Injury in Fact, and Private Rights, 93 CORNELL L. REV. 275 (2008) (arguing that the injury-in-fact requirement should not apply when Congress confers a right on private individuals).

168. Sunstein, supra note 167 , at 1475.

169. Sunstein, supra note 10 , at 167.

170. Id. at $171-78$.

171. Id. at 175. For an argument that the Court's willingness to accept qui tam actions renders standing doctrine an exercise in artificiality, see Jonathan R. Siegel, A Theory of Justiciability, 86 TEX. L. REV. 73, 105-08 (2007). See also id. at 136-37 (suggesting that standing serves little or no function in cases of widespread injury). Other scholars argue that the Court's approach to standing is based on earlier distinctions between public and private rights, see Ann Woolhandler \& Caleb Nelson, Does History Defeat the Standing Doctrine?, 102 MICH. L. REV. 689 (2004), or is derived from limits on judicial power that were inherent in common law doctrines, Anthony J. Bellia, Article III and the Cause of Action, 89 lOWA L. REV. 777 (2004). As is so often the case, history on this matter is ambiguous. Even if these scholars are right, about the most that can be said is that a plaintiff must have some stake in a lawsuit beyond the desire to defend the public interest or to enforce federal law. That conclusion may be a barrier to those who view Congress as having plenary power to confer standing. However, the place-based standing advocated in this Article does not fall afoul of these concerns.

172. Sunstein, supra note 10 , at 185 . 
seems to be little basis for a historical argument that the term "cases and controversies" was understood in terms of a specific requirement that the plaintiff have suffered an injury in fact. ${ }^{173}$

Besides the core requirement of injury in fact, other aspects of the current test, such as the fairly traceable element, are open to criticism. The common law analogue to the fairly traceable test is the proximate cause requirement in torts. As first year law students learn to their dismay, proximate cause is an intellectual quagmire; there is no reason to import the doctrine into constitutional law. What a court thinks is fair or not fair in terms of allocating responsibilities for harm should not be a limitation on Congress and should not be read into Article III.

The redressability element is also open to question. If a plaintiff is not entitled to any form of redress, then the case fails on the merits. It makes little sense to say that the failure to qualify for relief is a jurisdictional bar. ${ }^{174}$ If that were true, then the statute of limitations would be a jurisdictional defense in a tort case, since it prevents the plaintiff from obtaining any relief. (Indeed, the plaintiff would have the burden of proof in federal court on this and all other affirmative defenses that might block recovery.) The question of whether the law actually does provide any redress for a claimed violation of the law seemingly goes to the merits, not to jurisdiction.

If the question is not whether the law does provide any redress but whether it could provide any redress, Congress could generally resolve the problem by providing for a nominal damage award. Either way, the redressability requirement has a dubious role in standing law. As a constitutional

173. As Sunstein and others have suggested, the idea that the existence of injury is a factual question is also in tension with the ability of Congress to create new causes of action. For instance, whenever Congress creates a new liability, it creates an injury-the refusal of the defendant to pay the plaintiff money that is owed under the statute. Suppose, for example, that Congress created a bonus for anyone reporting a violation of law to the federal government. The government's failure to pay the money on demand would be an injury in fact.

The only apparent way of avoiding this argument is to argue that Congress's power to create new forms of liability is limited to cases in which courts are willing to identify a preexisting injury to be remedied. The basis for such a limitation presumably would be along the lines argued by Justice Scalia, as an implication of Article II's reliance on the executive branch as the enforcer of federal law. This argument is made in Harold J. Krent \& Ethan G. Shenkman, Of Citizen Suits and Citizen Sunstein, 91 MICH. L. REV. 1793 (1993). But as Part I indicates, the Article III argument is bootless. In any event, if taken seriously, this argument would seem to deprive the federal courts of jurisdiction to hear claims that federal benefits such as social security were unlawfully withheld, since the plaintiff has no claim of a prior harm from the federal government (prior in the sense of predating the claim for benefits itself).

174. Richard Fallon argues that the results in standing cases are often influenced by remedial concerns. Fallon, supra note 156, at 664-73. If this assertion is correct, then the Court would do better to confront the remedial concerns directly. 
matter, however, what should be required is at most a tendency to redress the wrong. Where Congress has prescribed a remedy, at least, a court should be able to presume that the remedy has some tendency to accomplish the congressional goal and hence redress the violation. ${ }^{175}$

Thus, most aspects of the current tripartite test for standing are open to serious challenge. There is much to be said in favor of the view that the test for standing should simply be the existence of a cause of action (or more accurately, under rule $12(\mathrm{~b})(6)$ of civil procedure, of a more than speculative claim for relief). ${ }^{176}$ But there does not seem to be much judicial agitation for the cause-of-action approach. In Massachusetts $v . E P A,{ }^{17}$ for example, the majority and dissenting opinions were in complete accord regarding the tripartite test for standing.

Courts seem attached to the idea that a plaintiff must have some stake in enforcing the challenged law distinguishable from that of the public at large. The term "injury in fact" has appeared has appeared in 107 Supreme Court opinions and 2919 court of appeals opinions. ${ }^{178}$ And while history may not support the specifics of the current test, there may be more historical support for the general idea that the plaintiff must have a personal connection with the subject of the litigation. ${ }^{179}$

Even if Congress should have the ability to provide broader standing, the public may be more willing to accept litigation as legitimate if the plaintiffs are motivated by something more than ideology. Broadening the set of potential litigants increases the difficulty of knowing whether the plaintiffs are adequately representing the interests of others who are involved in the dispute and the likelihood that political methods of redress would be

175. This recommendation is demonstrated by procedural injury cases, where it is unnecessary for the plaintiff to show that correcting the procedural error will actually improve the plaintiffs situation.

176. See Bell Atlantic Co. v. Twombly, 127 S. Ct. 1955, 1964 (2007).

177. 127 S. Ct. 1438 (2007).

178. Westlaw search on July 29, 2007 (the search included both "injury in fact" and "injury-infact"). For comparison purposes, the phrase "establishment clause" appeared in 137 Supreme Court opinions and 1010 court of appeals decisions. Another author reports 64 cases since 1970 in which standing was an issue and 27 in which it was treated with significant discussion, of which nine were environmental. Houck, supra note 79, at $20 \mathrm{n} .118$. This figure is still a significant amount of precedent.

179. See supra note 171. Standing doctrine may serve some purpose where a group of people enjoys constitutional rights that as a practical matter can only be enforced jointly, if most members of the group would prefer to waive or at least not to exercise the right. See Eugene Kontorovich, What Standing Is Good For, 93 VA. L. REV. 1663 (2007). This rationale seems weaker when Congress has created a right to review for statutory violations by an agency, but perhaps it provides some support for continued insistence on an identifiable link between the plaintiff and the defendant's conduct. 
sufficient. ${ }^{180}$ These considerations seem too feeble to support a limit on congressional power to grant standing and too vague to generate a particular standard such as injury in fact. They do, however, suggest that in the absence of contrary congressional directives, courts might do well to screen out at least the extreme cases where plaintiffs have no plausible claim of a personal interest at stake.

Current standing doctrine is an inefficient tool for accomplishing these goals, not only because of the judicial investment that it requires, but also because of its notable inconsistency. As a leading treatise on administrative law observes, the Court's opinions applying the standard are "problematic"; they "cannot be reconciled either with each other or with the Court's decisions with respect to other types of injury." suggestion that the justices are swayed by their political views because the relevant legal standards are so "extraordinarily malleable." 82 Indeed, an empirical study of circuit court opinions on standing found that a "Republican judge is four times as likely as a Democrat judge to deny standing to an environmental plaintiff." 183 It seems implausible that unwarranted claims are so much more likely to appear before Republican judges than Democratic judges by a matter of providence; an ideologically influenced application of the tripartite test must be at work.

From just about anyone's point of view, this is an undesirable situation. The question is what can be done about it, given that the courts are unlikely to make the leap to a radically different approach such as the cause-of-action theory, regardless of its merits. Whatever academics may say, judges will likely want some limiting principle on the set of potential plaintiffs. The problem is identifying a test that is more workable and more in tune with the realities of environmental litigation. Part IV proposes a fairly modest revision in the current standing test, in the hope of avoiding some of the problematic aspects of the current approach. Admittedly, proposing such a revision runs the risk of striking academics as too timid and judges as too bold.

180. The place-based approach supports this function to some extent. By requiring that those who object to a policy find a plaintiff who is linked with the affected region, the place-based approach makes it difficult to challenge administrative actions that enjoy a consensus of support among the impacted community.

181. PIERCE, SHAPIRO \& VERKUIL, supra note 26, at 147.

182. Id. at 161 .

183. Id. 


\section{The Place-Based ApProach to ENVIRONMENTAL StandinG}

Perhaps the Court should start fresh, as Sunstein and others have argued. But it seems unlikely that this will happen any time soon. The concept of "injury in fact" has loomed large in the Court's recent jurisprudence, and none of the Justices seems to be agitating for change. On the assumption that a radical doctrinal revision is not on the horizon, it makes sense to explore more modest ways to retool standing law.

In modifying the current approach to standing, we should keep in mind the features of existing doctrine that motivate its acceptance and attempt to retain those features if possible. The injury-in-fact requirement serves two purposes that appeal to current courts (and perhaps have independent normative appeal). First, the requirement demands a kind of concreteness: It instructs the plaintiff to connect the defendant's action with some specific location rather than considering only its general global impacts. Sierra Club ${ }^{184}$ is the paradigm - it is the plaintiffs' desire to protect the pristine Mineral King Valley that gives their claim its appeal. Second, the plaintiff must have some personal connection with the case rather than pursuing only a generalized interest in ensuring compliance with the rule of law or in improving public policy. ${ }^{185}$ Insistence on such a personal connection was the basic holding in Sierra Club, and the Court has not wavered on this point since.

This Article proposes an alternative approach to environmental standing that respects these judicial intuitions, focusing on the connection between a plaintiff and the places affected by a defendant's actions. By requiring something other than the "undifferentiated public interest in executive officers' compliance with the law" as a basis for standing, the place-based approach avoids the charge that it allows Congress to "transfer from the President to the courts the Chief Executive's most important constitutional duty, to 'take Care that the Laws be faithfully executed."'186

184. Sierra Club v. Morton, 405 U.S. 727, 760 n.2 (1972).

185. As William Fletcher pointed out, unhappiness about government policy can have very real consequences. In the case of welfare cutbacks, for example, a person may feel "so strongly about the matter that he occasionally loses sleep after walking past homeless people sleeping in the streets, and he spends money he would not otherwise spend to support a private charity providing aid to the homeless." Fletcher, supra note 5, at 232. But sleepless nights worrying about a problem and donating money to solve it are apparently not what the Court means by individuated injury, though Fletcher is surely right that this is an "injury in fact," or at least one might say, "in fact an injury." See id. at 232.

186. Lujan v. Defenders of Wildlife, 505 U.S. 555, 576 (1992). As we have already seen, Article II is a red herring in the context of standing law-but those who disagree should find my standing proposal acceptable nonetheless. 
In principle, then, place-based standing should be acceptable to those who, like Chief Justice Roberts, emphasize the importance of requiring more than a generalized grievance. ${ }^{187}$

This proposal is not to deny that place-based standing is an innovation or to pretend that Justice Scalia will enthusiastically accept the idea-but it is not a revolution. It respects the judicial concerns that have made current doctrine appealing, as much as some scholars might disagree with those concerns.

With these preliminary observations about the strengths of current doctrine, we turn to a consideration of an alternative, which hopefully retains the appeal of current doctrine but without its undesirable baggage.

\section{A. The Argument for a Distinctive Definition of Environmental Standing}

Environmental law seems to provide the subject matter for much of the judiciary's struggle with standing issues, so as a practical matter cleaning up standing doctrine in this one area would do much to address the overall problem. There is, however, a good argument that environmental standing actually deserves distinctive treatment.

The current approach to standing is based on detecting a tangible harm, tracing it to the defendant's past or threatened action, and then confirming that judicial relief could cause a diminution in the harm. Thus, judicial application of the doctrine is ultimately tied to our technological and scientific abilities to detect harms and trace them to their sources. In the environmental area, these capabilities have been growing rapidly for many years and promise to do so in the future. The claim that fails to constitute injury in fact today will be shown to do so in the future.

In Lujan v. National Wildlife Foundation, ${ }^{188}$ for example, we could easily imagine a showing that the increased fugitive dust and other pollution from mining activities would have a detectable health effect on residents of the general area. If this effect is not detectable today, then it will likely be detectable tomorrow, at least in the form of subclinical biological changes, such as chromosome damage that has not yet resulted in any overt symptoms of disease. As our scientific abilities grow, it will become increasingly less difficult to find plaintiffs who can show some impact from any major

187. Indeed, two prominent defenders of Justice Scalia's approach have agreed that Congress can unproblematically allow suit to be brought by those who have not themselves suffered an injury, but are acting on behalf of others who have been so injured, provided that those who bring the suit are appropriate representatives of those who have suffered injury. Krent \& Shenkman, supra note 173 , at $1817-18$.

188. 497 U.S. 871 (1990). 
governmental action affecting the environment. Since these very impacts are the basis for government regulation, it will be increasingly difficult for courts to dismiss them as too insignificant to form a basis for standing. Those who are in the vicinity of a government action will be increasingly able to provide scientific evidence to support their claims of harm.

Even apart from physical impacts, the Court has already defined standing in such a way as to invite claims by anyone with a significant physical presence in the affected area. If the effects of the defendant's conduct are visible, the plaintiffs may claim an aesthetic injury. If the effects are invisible, the plaintiffs may follow Laidlaw and claim that they have modified their behavior even if they cannot show a significant degree of harm to the environment or any actual physical risk. Or perhaps the plaintiff is a government unit and may claim an injury to its quasi-sovereign interests under Massachusetts v. EPA. Thus, existing jurisprudence already brings the courts halfway to a place-based approach. This Article takes the next step by recognizing the ultimate futility of attempting to disprove such claims. We might just as well presume that everyone in the affected area has an interest of some kind in the local environment and in limiting potential threats to that environment-this proposal is only a small step beyond existing jurisprudence.

Taking this small step would not endanger the distinction between general political grievances and concrete legal disputes. Rather, it would merely recognize that humans are intimately and deeply connected with their geographic surroundings, and therefore have legitimate cause for complaint about environmental violations that impact those surroundings. Environmental statutes are based on a congressional recognition of the pervasive connections between human welfare and the surrounding environment, ${ }^{189}$ and courts should acknowledge and give effect to this understanding.

Arguments for restricted standing in other types of litigation may not apply in environmental cases. For instance, restricting standing may limit the number of cases in which courts exercise their powers of constitutional

189. For instance, in the National Environmental Policy Act, Congress "recognize[ed] the critical importance of restoring and maintaining environmental quality to the overall welfare and development of man," and declared a national policy to "create and maintain conditions under which man and nature can exist in productive harmony, and fulfill the social, economic, and other requirements of present and future generations of Americans." 42 U.S.C. $\S 4331$ (a) (2000). Similarly, in the Clean Air Act, Congress found that "the growth in the amount and complexity of air pollution brought about by urbanization, industrial development, and the increasing use of motor vehicles, has resulted in mounting dangers to the public health and welfare, including injury to agricultural crops and livestock, damage to and the deterioration of property, and hazards to air and ground transportation." 42 U.S.C. $\$ 7401$ (a)(2). 
interpretation; some may find that desirable because of a fear that excessive constitutional review will unduly impair democratic governance. Environmental litigation is almost always statutory, and thus this consideration is absent.

Environmental statutes, because they relate to the physical environment, often have a geographic focus. This may take a variety of forms: environmental quality standards for bodies of water or for air basins, regulations preventing discharges of toxic substances into neighboring areas, statutes preserving wilderness, or laws protecting species that are found in some places but not others. Thus, the place-based standard for standing coheres with the overall structure of much of environmental regulation.

\section{B. Reinterpreting Injury in Fact in Terms of Geographical Nexus}

The place-based approach can be easily described. Under a place-based approach to standing, a plaintiff has standing to contest environmental violations involving a specific area, provided that the plaintiff has some personal connection to the area. In the spirit of the Court's evident attachment to three-part tests, we could break place-based standing into three elements:

(1) The "violation" element. There must be a violation of an environmental statute by the defendant, or at least a colorable claim that there has been such a violation. By requiring the presence of an environmental violation, we invoke Congress's implicit finding that the defendant's conduct has widespread (if not always readily traceable) consequences.

(2) The "area" element. The violation must involve a specific area. Environmental violations may involve a specific area either because the relevant conduct occurs there or because there is a credible claim that the violations affect the area.

(3) The "connection" element. The plaintiff must be personally connected with the area in question. A personal connection could take the form of residence in the area or use of the area for recreational or other purposes. ${ }^{190}$

190. A recent Ninth Circuit decision provides a helpful discussion:

Daily geographic proximity, for instance, may make actual past recreational use less important in substantiating an "injury in fact," because a person who lives quite nearby is likely to notice and care about the physical beauty of an area he passes often.... On the other hand, a person who uses an area for recreational purposes does not have to show that he or she lives particularly nearby to establish an injury-in-fact due to possible or feared environmental degradation. Repeated recreational use itself, accompanied by a credible 
This approach to standing retains both the requirement of concrete injury and the requirement of a personal connection-but it allows for a little play in the joints between the two. It is enough if the plaintiff's conduct and history evinces a sense of care about the local environment, without showing a precise connection with the specific environmental harm at issue.

The underlying motivation for this approach is simple. As Justice Douglas said in his Sierra $\mathrm{Club}{ }^{191}$ dissent in terms of standing to complain about harm to a river, "[t]hose people who have a meaningful relation to that body of water-whether it be a fisherman, a canoeist, a zoologist, or a logger-must be able to speak for the values which the river represents and which are threatened with destruction."192 The place-based approach also finds support in Laidlaw, ${ }^{193}$ where the Court allowed users of a river to protest trace amounts of pollution, without a showing that the pollution was in fact environmentally harmful, because a reasonable fear of the pollution disrupted their relationship with the river in terms of the kinds of uses they made. ${ }^{194}$ Although the Laidlaw Court did not refer to Justice Douglas's observation, in effect it adopted a similar view but in a more comfortably legalistic manner.

Place-based standing also seems eminently consistent with the Administrative Procedure Act, which grants judicial review to any person "suffering legal wrong because of agency action, or adversely affected or aggrieved by agency action within the meaning of a relevant statute." 195 Within the meaning of an environmental law, those persons who live in an area or pursue recreational opportunities there can reasonably be considered aggrieved by a violation of that environmental law involving their environment.

In most cases, it should not be difficult to define the boundaries of the place in question simply on the basis of common sense, such as Mineral King Valley in Sierra Club. The plaintiff's own activities help to define the space

allegation of desired future use, can be sufficient, even if relatively infrequent, to demonstrate that environmental degradation of the area is injurious to the person.... An individual who visits Yosemite National Park once a year to hike or rock climb and regards that visit as the highlight of his year is not precluded from litigating to protect the environmental quality of Yosemite Valley simply because he cannot visit more often.

Ecological Rights Found. v. Pac. Lumber Co., 230 F.3d 1141, 1149 (9th Cir. 2000).

191. Sierra Club v. Morton, 405 U.S. 727, 743 (1972).

192. Sierra Club, 405 U.S. at 743 (Douglas, J., dissenting).

193. Friends of the Earth, Inc. v. Laidlaw Envtl. Servs. (TOC), Inc., 528 U.S. 167, 181 (2000).

194. Laidlaw teaches that harm to the environment is not a requirement for standing. See 528 U.S. at 181 ("The relevant showing for purposes of Article III standing, however, is not injury to the environment but injury to the plaintiff."). This teaching is respected by the place-based theory, which requires that the place be involved but not necessarily harmed.

195. Administrative Procedure Act, 5 U.S.C. $\$ 702$ (2000). 
that is relevant to his life. A list of other relevant factors is easy to provide: geographic features, traffic flows, economic use patterns, environmental interconnections, and political boundaries may all be relevant. It is also relevant that an area has received a name of its own, showing that people conceive of it as a defined space. Defendants will probably argue for narrow definitions; plaintiffs will seek broader ones. This issue is not one that courts are incapable of addressing. It may involve judgment calls in some cases, but in many cases there will be a simple common sense answer-either the plaintiffs live in or visit the area impacted by emissions, or they do not.

\section{Refining the Theory of Place-Based Standing}

Some subsidiary points should be made about the requirement that the defendant's conduct involve a specific geographic area. Sometimes the defendant's conduct will physically occur in the area in question or will explicitly relate to that area (such as information disclosure about activities there). When this is not true, what should be required is a credible claim that the conduct has caused an environmental impact in that area. Because this requirement is reminiscent of the current injury-in-fact test, it is important to point out some distinctions.

First, what should be required here is not proof at trial but a credible basis for alleging that the violation involves the location in question. Even under the injury-in-fact approach, it is a mistake to think that standing vanishes if the trier of fact eventually decides that the defendant's conduct did not result in harm. ${ }^{196}$ We can see this clearly by considering an ordinary tort case. Suppose the jury finds that the defendant's tortious conduct did not result in damages, or that the defendant was not in fact the tortfeasor. If an injury in fact caused by the defendant is required, the jury would find it did not exist. Thus, the jury's verdict establishes that the elements of the current three-part standing test were not actually satisfied. Yet it would be bizarre to dismiss the case for lack of jurisdiction. ${ }^{197}$ The same is true of the causation requirement; a tort plaintiff who fails to prove an impact on the place in question should face a dismissal on the merits, not a dismissal for lack of jurisdiction.

In order to establish jurisdiction, it should be enough that the plaintiff has presented a credible allegation, subject to the usual rules about good faith

196. This point seems to have been muddled by the Laidlaw majority.

197. For similar reasons, if we take the injury-in-fact language too literally, we would believe that an acquittal in a criminal case would result in dismissal for want of Article III jurisdiction, since the defendant did not in fact cause any harm to the government's sovereign interests. 
pleading. ${ }^{198}$ Provided that the claim for relief is not "wholly insubstantial and frivolous," thereby defeating federal question jurisdiction, the Court should have Article III jurisdiction to consider the claim. ${ }^{199}$

Second, causation and redressability should not be independent elements of standing. ${ }^{200}$ The plaintiff should not have to show that the defendant's conduct caused harm to the plaintiff, but rather that the defendant's conduct relates to a place with which the plaintiff has a tie. When Congress has imposed a duty on the defendant, it can be presumed that breach of the duty is harmful and that the remedy created by Congress is beneficial to the environments that Congress was trying to protect. If Congress has required that the defendant obtain a permit, engage in an environmental assessment, release information, conform to certain pollution standards, or consult government agencies, the courts should not question the linkages between the violation and the proscribed remedy, on the one hand, and the tendency to improve the quality of the plaintiff's environment, on the other.

Finally, under the place-based approach it is nor necessary to make any special provision for procedural injuries. A plaintiff has standing to contest environmental violations involving a specific area, provided that the plaintiff has the requisite personal connection to the area. Whether the environmental violation is procedural, informational, or substantive is irrelevant, since there is no separate requirement of injury. Similarly, failure to disclose

198. Requiring that the court find an actual injury creates procedural difficulties when appellate courts exercise direct review over agency actions, since the court is not well suited for conducting a trial on the merits about the existence of the harm. Also, the question of whether a particular harm exists is often part of the issue that the agency itself is charged with deciding, so that by making a definitive finding on that fact the court would be prejudging the appropriate outcome of the administrative process. For example, in Massachusetts v. EPA, $127 \mathrm{~S}$. Ct. 1438 (2007), the plaintiffs standing claim was that carbon dioxide emissions from automobiles were causing harm to their interests, but the question of whether the emissions harm human welfare is also the statutory trigger for regulation, which the agency must apply on remand.

199. As a general matter, Bell v. Hood, 327 U.S. 678 (1946), establishes that the existence of a valid cause of action is not necessary to federal jurisdiction, unless the claim is a "wholly insubstantial and frivolous," id. at $682-83$; it is enough to establish jurisdiction that the plaintiffs claim arguably arises under federal law. See also City of Chicago v. Atchison, Topeka \& Santa Fe Ry. Co., 357 U.S. 77, 83-84 (1958) (noting that standing "could hardly depend" on whether the plaintiff's claim was actually valid). Although no more than this should be required for federal jurisdiction, the Court's recent decision in Bell Atlantic Corp. v. Twombly, 127 S. Ct. 1955 (2007), suggests that some degree of factual development may be needed to survive a motion to dismiss for failure to state a claim-but of course, that is a merits issue rather than a jurisdictional one.

200. Eliminating these elements is not as fundamental to this proposal, however, as focusing on place rather than plaintiff. A modified form of the proposal would require that the plaintiff have the requisite tie with a geographic area, and that the plaintiff show an injury to the area caused by the defendant that is redressable by the court. 
information is a ground for standing if the failure involved the relevant location (typically by relating to that location). Hence, there is no need for a special rule governing informational standing. Again, the place-based approach allows us to avoid the complexity that has grown up around the current test for standing.

If we wanted to fit the place-based approach into the current law of standing, we could do so using a combination of tools. We could carefully comb congressional statements of statutory purpose and relevant legislative history to find the kind of legislative basis for standing that Justice Kennedy suggested in Defenders of Wildlife (echoed by the Massachusetts Court). We could also press hard on the idea of procedural and informational injury, which at this point could apply to a large range of government actions, given the suggestion in Massachusetts $v$. EPA that judicial redress is itself a procedural right. Furthermore, we could probe the ways in which discomfort with a government action might lead a person to change his or her conduct, building on the Laidlaw approach. Quite possibly we could create a basis for standing in any given case that parallels the place-based approach without invoking it expressly. But this seems like an unnecessary complication. It is much simpler to admit that people have an interest in the overall environmental integrity of the spaces in which they live, work, and play, and that environmental violations necessarily threaten that integrity.

We can imagine a continuum of approaches to standing. At the most restrictive end is Justice Scalia's approach to injury in fact. At the most liberal end is the cause of action approach. In between are the liberalized injury-in-fact approaches of Laidlaw and Massachusetts, and place-based standing. These two liberalized approaches overlap. In some situations, the liberalized injury-in-fact approach might allow standing to a plaintiff without requiring a showing of a connection to any particular place. ${ }^{201}$ On the other hand, place-based standing may in practice provide for plaintiffs easier access to court than the liberalized injury approach, simply because of its simplicity and clarity.

\section{Applying the Place-Based Approach}

The place-based approach provides a straightforward way to find standing in cases like Laidlaw. Residents who used the river clearly qualify as having the requisite connection with the natural resource to complain about

201. We might want to leave this as an option for plaintiffs who for whatever reason prefer to proceed along this avenue. 
illegal discharges. Similarly, the state of Massachusetts obviously is an appropriate plaintiff to complain of erosion on its coastline hastened by climate change. ${ }^{202}$ Neither case is problematic.

What about the cases in which the Court has rejected environmental standing? The relevant cases are Defenders of Wildlife, ${ }^{203}$ National Wildlife Foundation, ${ }^{204}$ and Steel Co. ${ }^{205}$ Defenders of Wildlife and National Wildife Foundation present similar problems about the sufficiency of the affidavits. The Court faulted the affidavit in Defenders of Wildlife because, while they alleged past visits and a desire for future visits, they did not establish a clear likelihood of a future return. (There was also a question of whether "ecosystem" was so broadly defined that it eliminated any realistic geographic nexus with the activities in question. ${ }^{206}$ In National Wildlife Foundation, the Court thought an allegation of visits "near" the areas in question was insufficient given the size of the territory involved. ${ }^{207}$

On their facts, these decisions may have been excessively demanding in regard to the wording of the affidavits in question. The purpose of the inquiry, however-to establish whether the individuals had a sufficient connection with the area in question-would remain appropriate under the place-based approach. The outcomes in these cases relate less to the substance of standing than to the Court's insistence on a high degree of specificity at the summary judgment stage, which is really an issue of civil procedure. Given that standing is a threshold issue, however, it seems dubious that it should be subject to steep procedural demands, lest the merits of the case be lost in procedural wrangling. In any event, the outcome in these cases seems arguable based on their facts, though Justice Scalia's rhetoric would find little footing in a place-based approach.

In contrast, Steel Co. was plainly incorrect under the place-based approach. The plaintiffs in Steel Co. sued for failure to file timely reports about toxic chemicals, but by the time of suit, the reports had been brought up to date. ${ }^{208}$ The Court threw out the case on the basis of the redressability

202. For similar reasons, the Ninth Circuit was correct in holding that an Indian tribe had standing to protest a geothermal project, when it had "used the lands in question for cultural and religious ceremonies 'for countless generations."' Pit River Tribe v. United States Forest Serv., 469 F.3d 768, 779 (9th Cir. 2006) (quoting brief for petitioner).

203. Lujan v. Defenders of Wildlife, 504 U.S. 555 (1992).

204. Lujan v. National Wildlife Federation, 497 U.S. 871 (1990).

205. Steel Co. v. Citizens for a Better Env't, 523 U.S. 83 (1998).

206. See supra text accompanying notes 47-50.

207. See supra text accompanying notes 39-40.

208. See 523 U.S. at 87-88. 
prong of the conventional standing test. ${ }^{209}$ Some of the relief requested by the plaintiffs, according to the Court, was unavailable, while other relief (payment of civil fines) to the government, did not "redress" the harm to the plaintiffs from the past failure. ${ }^{210}$ Redressability is not, however, a part of the test for place-based standing. The violation involved toxics that were in the plaintiffs' vicinity and information that was clearly relevant to them; ${ }^{21}$ under the place-based approach this is sufficient to establish standing.

This leaves us with two potentially problematic cases in which the Court found standing: SCRAP ${ }^{212}$ and Duke Power. ${ }^{213}$ The place-based approach would not provide a basis for standing in Duke Power. The plaintiffs in Duke Power did make a credible claim that a nuclear power plant might cause harm to the local environment—but the place-based test makes such a claim only a basis for complaining about environmental violations, and the plaintiffs' claim on the merits was about the constitutionality of a potential limitation on their future right to obtain damages, not about a violation of some environmental law. Because their complaint was not environmental, place-based standing does not come into play, and the case would have to be considered under the residual standard for other, nonenvironmental standing claims, presumably the current tripartite test.

The question in SCRAP is whether the plaintiffs made a credible claim that the defendant's conduct (approval of a temporary rate increase for recycled materials) affected their local environment. The problem is not so much the chain of causation-it seems plausible that higher freight rates for recycled materials would reduce recycling and hence increase litter at least in some places. Some might question, however, whether the effect on the areas used by the plaintiffs was so completely negligible as to be pretextual. The Court found the allegations reasonable enough, at least at the pleading stage, ${ }^{214}$ but some current judges might disagree and conclude that the littering effect was too insubstantial to make the case relevant to any specific geographic area. The question seems again to be partly a function of varying attitudes on matters of pleading and procedure. It should not take very much evidence, however, to establish a credible basis for such a claim.

As some of these examples indicate, place-based standing does not entirely eliminate the need for judgment calls. Reasonable people will

209. See id. at 105.

210. See id. at $105-06$.

211. 523 U.S. at 104-05.

212. United States v. Students Challenging Regulatory Agency Procedures, 412 U.S. 669 (1973).

213. Duke Power Co. v. Carolina Envtl. Study Group, Inc., 438 U.S. 59, 74 (1978).

214. See supra text accompanying notes 24-25. 
sometimes disagree about whether a particular environmental violation involves a specific area or about whether a particular plaintiff has demonstrated sufficient ties to an area. But these are small, manageable issues. They are akin to other issues that courts handle fairly routinely, such as whether a given lawsuit has minimum contacts with a specific jurisdiction or whether a business has enough activities in a place to justify state taxation. Of course, the specific tests are different, but the point is that courts have great experience in considering the sufficiency of connections between locations and particular people and conduct. In the vast majority of cases, the answer will probably be clear. Moreover, plaintiffs will be on fair notice of what they have to prove to establish standing, rather than having to engage in speculations about what a court will consider sufficiently tangible or imminent, what chains of causation the court will think "fairly traceable," and what desired outcomes suit the judge's sense of remediation. The directive to plaintiffs' counsel is clear: determine the geographic scope of potential environmental impacts, and show that the plaintiffs have a plausible tie with the area in question.

\section{CONCLUSION}

Space and geography are irrelevant to much of our legal system. The existence of the state of Delaware is crucial to corporate law, but whether Delaware is as large as Texas or as small as Rhode Island, as cold as Alaska or as hot as Arizona, makes no difference to corporate law. Nor does most of the legal system attend to the basic reality that human beings are animals whose communities are anchored in specific landscapes. But these facts about human life are central to environmental law.

The place-based approach highlights the connection between people and the places where they live, play, and work. ${ }^{215}$ Place-based standing presumes that people have a stake in the environments they inhabit, unlike the current approach which assumes the contrary and requires individuals

215. In this sense, place-based standing reinforces a tendency that Professor Ann Carlson has identified in standing law more generally, which is to encourage environmental groups to emphasize the connections between humans and their local environments. Ann E. Carlson, Standing for the Environment, 45 UCLA L. REV. 931, 972-88 (1998) (discussing human-centered standing in contrast to resource-centered standing). However, the current approach does not retain what Professor Carlson sees as an important feature of the current approach-the encouragement to detail the specific interdependencies between people and their environments. Rather, under the place-based approach, courts would essentially presume this interdependence. As Professor Carlson suggests, however, it may nevertheless be useful for environmental groups to investigate and to publicize the specific interdependencies relevant to particular cases. Id. at 1002-03. 
to show that they are personally impacted by environmental violations. Thus, the place-based approach is more consistent with current public attitudes toward environmental issues (and indeed, with current scientific understanding of the environment).

Standing issues have vexed courts and commentators for the past several decades. Other commentators have offered to cut the Gordian knot, replacing current doctrine with a simple inquiry into the existence of a cause of action. So far, the justices have shown little interest in having their difficulties excised from the law. In terms of doctrinal revision, the proposal in this Article is more modest. Unlike more radical proposals, it respects the judiciary's view that a case should involve something more concrete than an abstract issue of law and that a plaintiff should have something beyond a generalized interest in law enforcement. While respecting these views that underlie current doctrine, the place-based approach seeks to implement them in a doctrinally simpler way.

Although less sweeping in legal terms, the place-based approach speaks to a more fundamental point than its alternatives. It asks us to see individuals, not just as legal actors who have the capacity to file law suits, but as people who live in a physical space and develop very real connections to their surroundings. ${ }^{215}$ It asks courts, in short, to develop a sense of place. Although standing law relates to a technical if not arcane aspect of federal jurisdiction, it also provides the setting in which courts bless certain individual interests as legitimate and others as ethereal. It is time for the courts to recognize that we all have an interest in the environmental integrity of our surroundings, rather than treating the environment as presumptively irrelevant to our lives and requiring individualized proof to the contrary.

216. As Mark Sagoff says,

A natural landscape becomes a place - "a shape that's in your head"-when it is cultivated, when it constrains human activity and is constrained by it, when it functions as a center of felt value because human needs, cultural and social as well as biological, are satisfied in it. ... This contrasts entirely with the attitude of the outsider . . . for whom "[n]othing has a drift or relation; nothing has a history or a promise. Everything stands by itself, and comes and goes in its turn, like the shifting scenes of a show, which leaves the spectator where he was."

Mark Sagoff, Settling America or The Concept of Place in Environmental Ethics, 12 J. ENERGY NAT. RES. \& ENVTL. L. 349, 358 (1992) (quoting MARK TWAIN, LIFE ON THE MISSISSIPPI 38 (1911); JOHN HENRY NewMAN, THE IDEA OF A UNIVERSITY 99 (Frank M. Turner ed., 1996)). Sagoff also presents an evocative quote from Alan Gussow: "A place is a piece of the whole environment that has been claimed by feelings."' Id. at 359 . 